\title{
FROM THE PANDEMIC TO THE RECOVERY: A LEGAL ANALYSIS
}

\author{
De la pandemia a la recuperación: un análisis legal
}

\author{
Biancamaria Raganelli \\ Associate Professor of Economic Law (University of Tor Vergata — Rome) \\ Pierre de Gioia Carabellese \\ Fellow of Advance HE (York, UK) and Professor \\ of Business Law and Regulation (ECU, Australia) \\ http://dx.doi.org/10.18543/ed-69(2)-2021pp185-227
}

Recibido: 24.11.2021

Aceptado: 13.12 .2021

\begin{abstract}
The Covid pandemic has raised various legal issues, fueling the scientific debate on the relationship between fundamental rights and freedoms in the global emergency context. Moreover, a case law has started developing within the different jurisdictions. Additionally, constitutional Courts, in different countries, have ruled over potential conflicts of interest among central powers and local ones, and even some decisa of the Court of Justice of the European Union have started "blossoming" in this area. Against the backdrop of this analysis, the paper discusses the main legal problems sparked off by the declaration of the state of emergency, with a focus on the main EU jurisdictions and with glimpses of non-EU countries. The aim of this is to discuss the balance between fundamental rights and liberties in decisa in different legal systems, as well as the interpretation given to principles of proportionality of the public health measures, adequacy, precaution and loyal collaboration and the relationship between freedom and limits to public power. Bearing this in mind, the purpose of the work is to demonstrate that, first and foremost, in Europe there is room for both a formal and a substantial recognition of common rights and liberties in terms of interpretation and application of constitutional traditions, shared by the different Member States. The relevant adherence to these principles is guaranteed by the
\end{abstract}


European Court of Justice. Second, the recovery after the pandemic is an open challenge. An important opportunity for Europe and its Member States is materialising, and this is to take a step forward on the bumpy path toward a European Political Union capable of strengthening a structure weakened by several earthquakes. A path and a project still plenty of pitfalls that needs to regroup around a central core increasing unification among European peoples (art. 1 TEU), which has never meant to be an alternative to national identity.

\section{Key words}

Emergency, pandemic, recovery plan, Italy and the UE, administrative and regional law.

\section{Resumen}

La crisis sanitaria originada por el Covid-19, ha traído aparejada numerosas y profundas cuestiones jurídicas que han afectado a todas las ramas del Derecho, alimentando un intenso debate científico en relación con los derechos y las libertades fundamentales garantizadas en el ordenamiento jurídico. Además, la excepcional situación generada por la crisis sanitaria ha tenido un claro reflejo en los Tribunales en las diferentes jurisdicciones. A ello no han sido ajenos, tampoco, los Tribunales constitucionales de los distintos Estados miembros de la Unión han tenido que abordar los problemas derivados del reforzamiento de competencias del Poder Ejecutivo y las restricciones de no pocos derechos fundamentales. Por su parte, el Tribunal de Justicia de la Unión Europea no ha sido ajeno a la crisis de salud pública provocada por la pandemia y ha tenido que adoptar ya unas primeras decisiones. En este trabajo se analizan los principales problemas jurídicos que ha suscitado la declaración del estado de excepción, centrándose en algunas de las jurisdicciones más relevantes de la Unión Europea, si bien, puntualmente, se incorporan referencias a algunos sistemas extracomunitarios. Y es que las circunstancias excepcionales han obligado a los diversos Estados de la Comunidad internacional a restringir los derechos y las libertades fundamentales. Pero, al mismo tiempo, el actual contexto ha puesto sobre la mesa diversas cuestiones críticas, la principal, la dificultad para actuar con proporcionalidad. El juicio de proporcionalidad sobre las medidas adoptadas (que las medidas limitativas sean adecuadas o idóneas para la consecución del fin perseguido; que sean la mínima imprescindible para tal finalidad y que haya proporcionalidad entre el sacrificio exigido al derecho limitado por esa medida y el concreto derecho, bien o interés que se pretende proteger) no puede hacerse al margen de los propios límites preestablecidos por los Ordenamientos. El derecho de excepción surgido de la crisis plantea, en última instancia, relevantes cuestiones en relación con el necesario equilibrio que ha de buscarse entre la garantía de los derechos fundamentales y los límites a que han de quedar sujetos los poderes públicos. Teniendo en cuenta lo anterior, el objetivo del presente trabajo no es otro que demostrar que en los ordenamientos de los Estados Miembros de la Unión Europea se garantizan tanto desde un punto de vista formal como sustancial o material los derechos y libertades conforme a las tradiciones constitucionales compartidas por todos ellos. En este sentido, el Tribunal de Justicia de las Comunidades Europeas no es ajeno a este planteamiento sino que 
asume esta misma línea.Europa afronta ahora un nuevo reto. La recuperación tras la pandemia brinda una nueva oportunidad para Europa y sus Estados miembros para dar un paso adelante en el accidentado camino hacia una Unión Política Europea capaz de fortalecer una estructura hoy debilitada. Un camino y un proyecto todavía lleno de escollos que necesita reforzar su unidad a través de una mayor identidad entre los pueblos europeos (art. 1 del TUE) sin que éstos pierdan su la identidad nacional.

\section{Palabras clave}

Emergencia, pandemia, plan de recuperación, Italia y la UE, emergency, Derecho administrativo y regional. 


\begin{abstract}
Sumario: I. Europe AND its unPRECEDENTEd Challenges. II. The DECLARATION OF THE "STATE OF EMERGENCY" IN SOME EUROPEAN COUNTRIES. 1. The legal state of exception in Italy. 2. The emergency management in the France, Spain and Germany. III. EMERGENCY, POWER AND FREEDOM "ACROSS THE OCEAN". 1. Freedom and limits to public power. 2. "Safer at Home Order" and its limits. 3. The emergency orders caveat. IV. THE BALANCE BETWEEN FUNDAMENTAL RIGHTS AND LIBERTIES IN DECISA. 1. On the proportionality of the public health measures. 2. Freedom of assembly, demonstration and proportionality. 3. The use of principles of proportionality and adequacy in Germany. 4. The use of principles of precaution and loyal collaboration in Italy. V. THE ECONOMIC AND FINANCIAL RECOVERY PLANS IN SOME EU COUNTRIES. VI. FINAL REMARKS. VII. BIBLIOGRAPHY.
\end{abstract}

\title{
I. EUROPE AND ITS UNPRECEDENTED CHALLENGES
}

The health crisis that hit Europe in the early 2020 has triggered reactions in different Member States and fuelled a lively debate about the course of action and proper reactions required to deal with these exceptional circumstances.

Solidarity, a theme evoked many times in the numerous, difficult situations that Europe needed to cope with since the end of the Second World War, has made its sudden comeback in the European political scene, in March 2020. Ultimately, Europe has faced a huge health emergency and, as a result of this, a new economic crisis. A change of mindset is called upon to overcome a common enemy and to make significant decisions for the safeguard of citizens and the economy.

The EU answer to the 2007/2008 financial crisis was a unified institutional and regulatory reform (brand-new pan-European authorities and forward-looking regulation), whereas, paradoxically, the post-pandemic answer has shown so far, mainly, uncertainties.

The future of the Union and of its people depends on the way governments will approach the crisis. Inner conflicts and nationalistic pressures have weakened Europe's response to the pandemic impact. Besides, the complexity of decision-making procedures and the multilevel interactions among governments, with politicians who have delayed the management of problems. The emergency has thus highlighted the main and most entrenched vulnerabilities of the Union, starting from the lack of political and fiscal integration, which should provide coherent answers to the single countries in difficulty in the name of the often-evoked issue of solidarity.

In the name of the ostensive emergency, the concept sovereignty has intensified, allowing the State to step up to the plate and to become the chief 
decision-making centre, fundamentally in isolation from the Union and the other Member States. As a result, Member States have introduced derogations from the general principles that, theoretically and quintessentially, govern the European single market.

Indeed, it has been maintained that the idea of sovereignty without States is groundless and that the supranational dimension could only grasp partial aspects of the problems, failing to become a compelling generalised or prevalent model. ${ }^{1}$ Therefore, the conundrum, which is also the subject matter of this paper, is to assess whether these stances are really correct. In other words, it is crucial to ascertain whether there is a growing feeling, among the people of the Union, to reverse the path and distance from each other, according to the different nationalities, by scrapping as a result the revolutionary idea, indeed revolutionary at the beginning but already enshrined in the Treaties, of both a single market and a European citizenship.

It would be worthwhile to reflect upon the limits so far recognised in order to overcome them, making this dramatic experience an opportunity to favour the development of a European sovereignty through a democratic process of political legitimization. This is the only way to curb any form of criticism, whose purpose, ultimately, would be to rebuild, via a suspension of Schengen Agreement, both old and new borders, these being understood either as limits of responsibility, or barriers against foreign ambitions (golden power) in the name of the alleged protection of citizens and companies.

A common strategy in the field of debt issuance and fiscal transfers are also necessary to overcome the on-going economic crisis ${ }^{2}$. This strategy may

${ }^{1}$ In Italy, see, more recently, F. Fracchia, Coronavirus, senso del limite, deglobalizzazione e diritto amministrativo: nulla sarà più come prima?, in Il diritto dell'economia, 2020, 579 s.; ID., Sovranismi, globalizzazione e diritto amministrativo: sull'utilità di un approccio dialogante e a più dimensioni, in www.federalismi.it, no. 17/2018. On the history of the term "sovereign" and its concept, see, among others, L. RAGGI, La teoria delle sovranità, Genova 1908; H. ReHm, Geschichte der Staatsrechtswissenschaft, Friburgo, 1896; ID., Allgemeine Staatslehre, in Handbuch des öffent. 1899; G. JELlinEK, Allgemeine Staatslehre, Berlino, 1929; H. KelsEn, Das Problem der Souveränität und d. Theorie d. Völkerrechts, Tubinga 1920; $2^{\mathrm{a}}$ ed., 1928; E. CROSA, Il principio della sovranità dello stato nel diritto italiano, in Archivio giuridico, 1933.

${ }^{2}$ L'ISTAT (the Italian Public Institute of Statistics), as far as the 2020/2021 Italian economic forecasts are concerned, predicted that, as of 2020, the Gross Domestic Product would suffer from a "strong contraction" equal to $8,3 \%$. These figures are slightly less than the Italian Government Forecasts, the latter data being encompassed within the "Documento di economia e finanza", the report of economics and finance. Furthermore, the International Monetary Fund predicted, for 2020, a global recession of 3\%, the worst one after the Great depression. For Italy, the IMF forecasts point to a contraction of the GDP of 9,1\% in 2020, whereas the European Commission, in its economic forecasts for spring 2020, recently published, predicts a contraction of the economy, within the whole 
drive a coach and horses through the current lack of political and fiscal union. This "time" of crisis needs to be "seized" as a golden opportunity to overcome the twofold Eurozone-UE level, in order to move towards a more integrated Europe from a monetary, banking, fiscal and political point of view for those countries that wish to be part of it.

The single countries have adopted a number of measures at the national level, which affected - and to a certain extent are still prejudicing - individual liberties and economic activities in different manner (infra par. 2). They have also seen their national courts issue contrasting and contradictory decisions (infra par. 3, 4). In this very complex scenario, the research question, on which the debate is focused on, is how and where to restart in Europe (infra par. 5) ${ }^{3}$.

The present paper proposes some reflections on the relationship among emergency, power, rights, and fundamental freedoms, analysing the hermeneutic criteria for their proper interpretation in a democratic framework. It also argues for their substantial acknowledgment in terms of interpretation, application and conservation, relying on the constitutional traditions common to the Member States.

\section{THE DECLARATION OF THE "STATE OF EMERGENCY" IN SOME EUROPEAN COUNTRIES}

\section{The legal state of exception in Italy}

As the virus spread in Europe, many countries adopted extraordinary measures in the name of the health emergency. This meant the imposition of limits to personal and economic liberties. On its turn, this has encouraged the debate on a number of crucial points, most notably the constitutional rights in the emergency state, the legitimacy of the restriction

EU, equal to 7,5\% (Spring 2020 Economic Forecasts). For an analysis on the impact of the financial crisis, see OECD, Evaluating the initial impact of COVID-19 containment measures on economic activity, latest update 14 April 2020.

${ }^{3}$ We should think about (i) restrictions on the free circulation of goods, and particularly the export relating to face masks, intensive care machines and other tools of individual protection, which look clearly against the prohibition of both quantitative restrictions to the export and of measures of equivalent effect (art. 35, TFEU); (ii) restrictions on the free circulation of individuals, in connection with which, in 16 Arch 2020, with a specific communication, the European Commission highlighted the possibility for the Member State to reinstate temporary controls at the internal borders within the Schengen area; (iii) to the measures of protection of the national businesses in some strategic sectors (so called "Golden power"). In France, for instance, as far as the obligation to wear the face mask is concerned, the decision of some local authorities to impose this obligation was, either partly or totally rejected. See ordennances no. 443750 and no. 443751 of 6 September 2020. 
measures and the democratic grounds of the decision-making process in consideration of the means adopted practically adopted, particularly the legal and legislative ones ${ }^{4}$.

In most measures, the basic assumption was based on the declaration of the "state of emergency". This expression is how the Covid-19 pandemic has frequently been regarded ${ }^{5}$. The notion at stake has been given different meanings among international scholars, with historical, political and legal implications. ${ }^{6}$ References to the "exceptional public danger", the "state of war" and "any state of crisis that threatens the independence and security of a Member State" can be found in the European Convention for the Protection of Human Rights and Fundamental Freedoms (1950), in the International

${ }^{4}$ Among the several scholars who embarked on this discussion, see L. Cuocolo, $I$ diritti costituzionali di fronte all'emergenza Covid-19. Una prospettiva comparata, in Federalismi.it, 2020; AA. Vv., Il senso di Diritti Comparati per la crisi: emergenza, protezione dei diritti fondamentali e radici europee, in Diritti comparati, 1 April 2020; C. ACOCElla, L'epidemia come metafora della sospensione e della compressione delle libertà fondamentali., in Diritti regionali, 2020; U. AlLEGRETTI, Il trattamento dell'epidemia di "coronavirus" come problema costituzionale e amministrativo, in Forum Quaderni Costituzionali, 25 marzo 2020, ID., Una normativa più definitiva sulla lotta all'epidemia del coronavirus?, in Forum Quaderni Costituzionali, no. 1/2020, 28 marzo 2020; G. AzZARITI, I limiti costituzionali della situazione d'emergenza provocata dal Covid-19, in Questione Giustizia, 27 marzo 2020; ID., Il diritto costituzionale d'eccezione, in Costituzionalismo.it, no. 1/2020, 31 marzo 2020; V. BALDINI, Emergenza costituzionale e Costituzione dell'emergenza., in Dirittifondamentali.it, 23 marzo 2020; ID., Riflessioni sparse sul caso (o sul caos...) normativo al tempo dell'emergenza costituzionale, in Dirittifondamentali.it, 2 April 2020; ID., Dignità umana e normativa emergenziale: (in)osservanza di un paradigma formale o (colpevole...) elusione di un parametro (anche) sostanziale? Aspetti problematici di un difficile equilibrio, in Dirittifondamentali.it, no. 2/2020, 6 maggio 2020; G. BARTOLINI, Alcune questioni dell'emergenza COVID-19 in Italia in un'ottica di international disaster law, in SIDI blog - Forum Covid-19, 21 maggio 2020; C. BotTARI, Alcune riflessioni sui profili organizzativi ai tempi del coronavirus, in giustizia-amministrativa.it, 4 maggio 2020; B. CARAVITA, L'Italia ai tempi del coronavirus: rileggendo la Costituzione italiana, 18 marzo 2020, in Federalismi.it, 5.

${ }_{5}$ Within social sciences, the expression would refer to unexpected circumstances of concern or danger, albeit of a temporary nature but not of a short period. These circumstances, as qualified herein, would entail a crisis in the functioning of the institutions operating within a specified group or section of the society (on this aspect, see A. PIzzorusso, voce Emergenza, stato di, in Enciclopedia delle scienze sociali, Treccani, 1993).

6 The Carl Schmitt's theory, advocated in 1922, according to which the ability to resolve on the state of exception would represent the essential feature of the sovereignty, has been the diriving force for Nazism to seize and strengthen its power in Germany, through a decree of emergency for the protection of both the German people and the State, dated $28^{\text {th }}$ February 1933. In Latin America too, in the 70', in some countries the state of emergency was used mainly to allow some groups, particularly the military ones, to get the power. 
Covenant of Civil and Political Rights (1966), and in American Convention on Human Rights (1969), albeit with specific limitations and guarantees.

The Italian Constitution does not include the "state of emergency" in explicit form, however art. 77 governs the «extraordinary cases of necessity and urgency ${ }^{7}$, which allows the government to perform the legislative function $^{8}$, while the art. 78 empowers the Chambers to declare the state of war and confer the necessary powers to the government ${ }^{9}$.

From the view point of Italian politics, the Covid-19 pandemic has often been characterised as "war", which would theoretically make the application of art. 78 conceivable. ${ }^{10}$ At first, China was the only reference model, although the characteristics of the Chinese State are not fully comparable with the "Western democracies". ${ }^{11}$ The Italian government decided to centralise the power of the Minister of Health in the hands of the Prime Minister ${ }^{12}$, taking emergency measures with regulative power in the form of decrees of the President of the Council of Ministers ("DPCM", to use the Italian acronym). Ultimately, the

7 Our translation.

8 Among the others, see Constitutional Court, no. 93/2011, 171/2007.

9 The Italian Constitutional Assembly discussed the proposal aimed to include in such an article situations and circumstances which differ from the "international war emergency". However, the opposite view prevailed, eventually, on the ground that to suspend the rights of freedom in further circumstances would be tantamount to suspend the same idea of democracy. Ultimately, this would have been a "clear contradiction" (Cherchi). As far as the state of emergency is concerned, a piece of "ordinary" legislation, the law, particularly Law. no. $225 / 1992$, associated with law decree $1 / 2018$, deals with that.

${ }_{10}$ A parallel between the war and the spread of the SARS-CoV-2, is drawn by a some Scholars, particularly, F. FRACCHIA, Stato e Forze Armate: la specialità del relativo ordinamento a presidio della sovranità, Review of the Riccardo Ursi's monograph, R. Ursi, L'amministrazione militare, Torino, 2018, Riv. it. dir. pubbl. comun., forthcoming; ID., Coronavirus, senso del limite, deglobalizzazione e diritto amministrativo, op.cit., 575 ss. The Author advocates the view that the terminology adopted by both the politicians and the media (war, emergency, fight, attack, defences, patriotism, the pride of being Italian,) makes plausible the association between health emergency and war.

${ }^{11}$ By contrast, there are those who challenge the same characterisation of "emergency". Therefore, they claim that the regulation adopted is pretty confused and contradictory. This regulation would impinge on both obligations and prohibitions devoid of scientific and legal grounds In this respect, see the application of self-defence (a peculiar Italia administrative tool, called in the language of origin "istanza di autotutela" (self-protective application", lodged by some doctors (P. M. Bacco, A. Gatti, M. Amici, C. Rescigno, F. Milani, M.G. Dondini) before the President of the Board of Ministers, before the Minister of Health, and the President of the High Health Body. The application was sent in c.c. to each President of the twenty Italian regions.

12 According to the 1978 piece of legislation governing the Italian Health Service System, "Servizio Sanitario Nazionale", competent to pass more than half of those acts of what, later on, would be the Ministry of Health. 
legitimacy of the various DPCMs passed since the start of the "Pandemic" have been based on Legislative Decree no. 6, 23 February 2020, which allowed the Prime Minister to adopt "any measure of containment and adequate and proportional management of the evolution of the epidemiological situation" (our translation). ${ }^{13}$ In Italy, there have been different DPCMs (Decrees of the Prime Minister) for the implementation of law decrees aimed at fighting the pandemic and promoting the economic revival of the country.

The choice of this legal tool or instrument has been the subject matter of discussion, also in view of the implications as to the fundamental rights and freedoms entailed in such decisions. Yet, such debate has been weak and blurred in networks and newspapers, whereas it has played a relevant role in the interpretation, conveyance, moral suasion and quasi-enforcement of the government instructions.

Italian people went through the slogan "I stay home", the mantra "it will be fine", to the order to "stay home", with the menace of sanctions and forms of prosecution. This surreal atmosphere, with television networks broadcasting videos of drones chasing riders and runners, permeated people's lives for over two months, ${ }^{14}$ but also during the following two full lockdowns, in Autumn/Winter 2020/2021, and around Easter 2021. It has been highlighted that the Italian Constitution points directly to public bodies offering adequate safeguards: the Parliament and the President of the Republic, which cooperate in the normative function and dispose of different emergency strategies, along with the Constitutional Court that generally acts ex post $t^{15}$.

On the other hand, the compliance of the measures adopted with the Constitutional values has been defended, based on art. 16, 17 and 32, Italian Constitution, and the limitations to be established by law for health and security reasons. The legal state of exception imposed by the government has thus

${ }^{13}$ In force of law decree 23 February 2020, no. 6, some measures aimed to contain and menage the epidemiological emergency have been introduced. This law decree has been followed up by Law Decree 2 March 2020, no. 9, Urgent Measures of support for families, workers and businesses connected with the epidemiological emergency. Among the number of contributions in this area, see R. CAVAllo Perin, Pandemia 2020: decreti e ordinanze d'emergenza, in Giustiziainsieme.it, 15 maggio 2020; F. Cintoli, Sul regime del lockdown in Italia (note sul decreto legge no. 19 del 25 marzo 2020), in Federalismi.it.

${ }^{14}$ The image call upon the famous section of one of the pieces of the Italian Modern "Bard", Alessandro Manzoni. See A. Manzoni, I Promessi sposi, cap. XXXIV, 1827. In this section, Renzo, the main character of the Novel, is chased by a woman who screams at him with the expression "the infector, go to hell, go the infector to hell". In doing so, the woman wanted to draw the attention of the passers-by and people more in general.

15 S. CASSESE, La pandemia non è una guerra. I pieni poteri al governo non sono legittimi, in Il dubbio, 14.04.2020-. Likewise, E. CHel, Poteri, diritti, competenze. I problemi costituzionali sorti dal Covid, Huffingtonpost.it, 22.06.2020. 
been "anchored" to the health needs and public safety, albeit with much discussion within the international scientific community as to the "an, quando, quantum e quomodo"16, therefore if, when, how much and how. The emergency measures adopted have been built on the safeguard of the right to health ${ }^{17}$ acknowledged in the Constitution as the qualifying element of the social State, with respect to which the public power acts as a regulatory authority and public service supplier.

However, it must also be borne in mind that in Italy this right to health, certainly emphasised during the pandemic, has not always been regarded as an absolute one, in previous applications. In the case affecting Taranto, a city in Apulia deadly affected by the consequences of the poisonous activity of the biggest steel factory in Europe, literally laying at the doors of the city, close to the city centre, the request of the local stakeholders, such as residents, who lodged legal claims before the local Court aimed to stop the industrial activities of this factory, were dismissed on the ground that the right to health, constitutionally protected, needed to be counter-balanced by the right of freedom of economic activity, set forth under art. 42 of the same Italian Constitution. By contrast, when the matter of the health has become "national", rather than local, like for the pandemic, the health has resulted in overwhelming any other constitutional right.

Ultimately, in dealing with art. 32and its right to health, the conundrum is to draw a clear demarcation line around its concept, since the Taranto case, on the one hand, and the Pandemic one, on the other hand, show a quite different and, perhaps, contradictory approach ${ }^{18}$.

It is also worth recalling that in international law there is a principle, summarised by the maxim "necessitas non habet legem"19, according to which a state of necessity does not even require a law. Although this concept is entrenched, it should not be forgotten that the maxim dates back to a time where Constitutions did not exist. The "necessitas", the necessity, as existence of exceptional circumstances, has allowed in the past military forces to

${ }^{16}$ Discussions have dealt also with the ways pieces of data are collected. The interpretation of data, and the ways they are presented, have also been the subject of discussion, with contrasting views of the experts.

17 The Italian Constitution stipulates the right to health pursuant to its art. 32. Furthermore, the right to health is encompassed with both the European Union Treaties (namely, pursuant to art. 168, TFEU, previously art. 152 Treaty of the European Community) and international frameworks (namely, art. 2 of the International Treaty on economic, social and cultural rights, New York, 6 December 1966).

${ }^{18}$ As far as the actual meaning of the right to health enshrined in art. 32 of the Italian Constitution, see Osservatorio AIC, 2020(3).

19 A. Candido, Necessitas non habet legem? Pandemia e limiti alla libertà di circolazion, in Quaderni costituzionali, 2020(2), pp. 376-379. 
nonchalantly take over the power, by turning quasi democratic States in actual quasi dictatorships. Paradoxically, in a country and legal system, Russia, not always regarded, in the political rows of the last decades, the paradigm of the democracy, the Constitution, at its art. $56^{20}$, offers a very clear definition of the concept of need, and it encompasses, explicitly, the health as one of the circumstances where Constitutional laws may limit the fundamental rights.

The centralisation of power in the hands of the Government has improved, ${ }^{21}$ calling upon the Constitution as it allows the government to substitute local authorities for public safety ${ }^{22}$.

In particular, the measures adopted by the Italian State brought about limitations and restrictions on fundamental freedoms, among which the freedom to move, to practice religion in group, the right of economic initiative and of respect of the family life, as well as of instruction. In most cases, the Italian jurisprudence has dismissed the actions against the emergency measures ${ }^{23}$. The reason for this is that these rights are acknowledged in the European Convention for the Protection of Human Rights, based on the principle of

${ }^{20}$ In its English version, art. 56 is worth being recalled:

"1. In a state of emergency, certain restrictions of rights and freedoms, with indication of their extent and duration, may be introduced in accordance with a federal constitutional law in order to ensure the safety of citizens and protection of the constitutional system.

2. A state of emergency on the whole territory of the Russian Federation and in its certain areas may be introduced in the circumstances and in the manner stipulated in a federal constitutional law.

3. The rights and freedoms stipulated in Articles 20, 21, 23 (Part 1), 24, 28, 34 (Part 1), 40 (Part 1), 46-54 of the Constitution of the Russian Federation are not subject to restriction."

${ }^{21}$ C. Della Giustina, "Quel che Resta della Costituzione Italiana dopo 1'Emergenza Sanitaria Covid-19. Reflessioni in Materia di Regionalismo Differenziato e Tecnocrazia" (2020)2 Dirittifondamentali.it 1563-1579.

22 Art. 120, paragraph 2, Italian Constitution. As well known, art. 117, paragraph 2, lett. $\mathrm{m}$ ), which reserves to the central state the legislative competence in the matter of "determination of the essential levels of the performances concerned with the civil and social rights which must be guaranteed on the whole national territory"; by contrast, art. 117 , paragraph 3 , sets forth the concept, indeed very Italian and peculiar, of the concurrent or competing competence in the area of "protection of health".

${ }^{23}$ Most Italian case law has confirmed the measures and rejected the claims. Among the different administrative decisa, see T.A.R. Campania, Napoli, section 5, ruling 18 March 2020, no. 416, which encompasses a rejection of the suspension of the decision (ordinanze) of the President of the Campania region. These ordinanze enforced a prohibition to practice sport, including the outdoor one, and particularly the prohibition to practice "sport activity, games, or outdoor recreational activity in public places or open to the public" (our translation). For further references to the Italian case law, see the penultimate Chapter. 
subjection of the exercise of public power to criteria of democracy, rule of law and respect of human dignity.

As known, the Convention includes temporary derogations and limitations for particular needs ${ }^{24}$. The art. 15 allows to adapt the principles of legality, necessity and proportionality in strict sense, and this should strike the balance between human rights and collective interests on situations that do not allow the assessment of the single case. ${ }^{25}$ However, it needs to be clarified whether every singe measure has overcome the limits established in each clause of limitation ${ }^{26}$. These limits are subject to the scrutiny of the European Court of Human Rights, considering the general approach according to which the limitation of a right cannot compromise the essence of the right and the ambiguity that lie within the scrutiny of the judgment, which imposes the limitation when needed.

It would have been appropriate to follow the example of other European countries notifying the declarations in derogation as far as the threatened rights are concerned, such as the freedom of movement and association. This would have justified the application of the art. 15. Furthermore, it would have demonstrated that the limitation of the fundamental rights was confined to what it is strictly necessary, according to the principles inspired to the highest democratic values ${ }^{27}$.

${ }^{24}$ Pursuant to artt. 8-11 and art. 2, Protocol 4, ECHR, limitations on individuals' rights may be imposed, so long as these derive from "necessary measures in a democratic society" to safeguard, among other aspects, the public health. For a commentary, see among the others L. ACCONCIAMESSA, COVID-19 e diritti umani: le misure di contenimento alla luce della CEDU, in Ius in Itinere, 2020.

${ }^{25}$ G. Cataldi, Art. 15. Deroga in caso d'urgenza, in Commentario breve ala CEDU, in A. Bartole, P. De Sena e V. Zagrebelsky (eds), Padova, 2012, 555. The philosophical and normative foundation of the legal provision should be found in the theory of the state of necessity. This theory is essential to justify also situations of emergency within conventional mechanisms, so that it is guaranteed that the exceptional nature of the danger be not called upon to justify, rebus sic stantibus, whatsoever limitation of the fundamental rights. On this topic, see R. Alexy, A Theory of Constitutional Rights, with English translation by J. Rivers, Oxford, 2002 (original in German dated 1985). On the topic of the "balance", see among others also AA. Vv., Il processo, luogo della tutela dei diritti anche e soprattutto nell'emergenza. Dialogando con il Presidente Patroni Griffi sulla giustizia amministrativa, in Federalismi.it, no. 13/2020, 13 maggio 2020; A. Buratti, Quale bilanciamento tra i diritti nell'emergenza sanitaria? Due recentissime posizioni di Marta Cartabia e Giuseppe Conte, in Diritti comparati, 1 May 2020.

${ }^{26}$ Among the others, see on this specific issue A. SPADARo, Do the containment measures taken by Italy in relation to COVID-19 comply with human rights law?, in EJIL Talks, 16 March 2020.

27 E. M. Hafner Burton, L. R. Helfer e C. J. Farris, Emergencies and Escape: Explaining Derogations from Human Rights Treaties, International Organizations, 2001, 679. 


\section{The emergency management in the France, Spain and Germany}

In France, the notion of emergency entails a multiplicity of conceptual nuances that justify the adoption of exceptional measures that affect individual liberties. The French Constitution includes the possibility to impose restrictions for emergency reasons. ${ }^{28}$ In this way, the President of the Republic can acquire exceptional power for the safeguard of democracy, merging both the executive and the legislative power ${ }^{29}$.

In case of war or insurgency, the Council of Ministers can declare the état de siège $e^{30}$. The état d'urgence, instead, allows the administrative authority to adopt extraordinary measures by means of police power ${ }^{31}$. The state of emergency can be declared either in a part or in the whole territory, in case of serous menaces and dangers to public order ${ }^{32}$. To face the pandemic, the French government introduced a specific measure and enacted the ordinary emergency law Loi no. 2020-290 du 23 mars 2020 to provide for a legal ground for the emergency measures to adopt. The government has been empowered to legislate by means of ordonnances (art. 38 Cost.) and the l'état d'urgence sanitaire has been introduced in the Code de la santé publique ${ }^{33}$. In this piece of legislation, it is adequately clarified that the consequences of the

${ }^{28}$ For the President of the Republic to use exceptional powers, according to the Italian Constitutional laws, "condition precedent" is her/his previous official consultation with the Prime Minister, the Presidents of the two Chambers and, finally, the President of the Constitutional Court. After this complex process of consultations, an address to the Nation should ensue.

${ }^{29}$ Art. 16 of the Constitution of the "Fifth French Republic", the Conseil Constitutionnel ascertains whether the conditions justifying the conferment of such exceptional powers still persist.

${ }^{30}$ Art. 36 of the French Constitution. The declaration of the état di siége shall not exceed 12 days, except for postponements subject to the approval of the Parliament. See, among the different Scholars, J. LlAMARQUE, Légalité constitutionnelle et contrôle juridictionnel des actes pris en vertu de l'article 16, in JCP; F. SAINT-BONNET, Réflexions sur l'article 16 et l'état d'exception, in RDP 1998, Les quarante ans de la Constitution du 4 octobre 1958.

31 This concept is of an exceptional nature, and it is governed by Loi 1955-385, 3 April 1955. The état d'urgence, for example, was used in France as a result of terror attack occurred on 13 November 2015.

32 The Loi 1955-385 does not establish a shift of different powers among the various Italian Constitutional bodies, and it allows the adoption of extraordinary measures by the administrative authority. The administrative acts by the Italian Governments, as well as those adopted by those responsible for the Italian provinces (Prefettura), adopted before the declaration of emergency, set forth the possibility for the Minister of Health to "unleash" urgent measures proportionate to the risks and appropriate circumstances of both time and place.

33 Art. Law 3131-12, also referred to as Code de la santé publique (the Consolidate Law of Public Health) 
declaration of the state of emergency must be proportionate to the health risk and the specific circumstances of time and place.

The Spanish Constitution includes the state of emergency and further distinguishes between estado de alarma ${ }^{34}$, estado de excepción ${ }^{35}$, and estado de sitio $^{36}$, which entail the adoption of extraordinary and temporary measures. A political control by the Parliament is expected, which deliberates on the potential extensions in consideration of the compression of individual rights, of the duration and of the other conditions and terms ${ }^{37}$.

It has been debated which legal instrument would better face the crisis, especially considering the liberties and rights undermined, even if provisionally $^{38}$. The decision of declaring the estado de alarma ${ }^{39}$ in the whole national

${ }^{34}$ Art. 116, paragraph 2, of the Spanish Constitution, prescribes that the Government may take action, in force of a "decree" of the Ministers' Body, by referring to the Congreso de los Diputados (therefore the Parliamentary Chamber), immediately gathered to such an end. In its turn, the Congreso may authorise, or not, a delay of the emergency period.

35 The state of emergency, pursuant to art. 116, paragraph 3, of the Spanish Constitution, is declared by the Government via a decree passed by the Consejo de Ministros, so long as a previous authorisation by the Congreso de los Diputados (the Spanish Parliament) is given. See among others A. CuEnca Miranda, Alarma "excepcional", in Papeles faes fundacion, no. 236 del 23/03/2020; ID., El derecho ante el coronavirus, in Diario ABC, dell'11.03.2020.

${ }^{36}$ In force of art. 116, paragraph 4, Spanish Constitution, the "state of siege" shall be declared, with utmost urgency, with the absolute majority of the Congreso de los Diputados, upon exclusive request of the Government. The Spanish Parliament shall establish the relevant area, time and conditions of this state of siege.

37 As clarified by the Sentencia del Tribunal Constitucional 83/2016 (a decision by the Constitutional Tribunal), such a control shall not change the exclusive nature of the competence of the Government concerned with the initial declaration of the state of alert per a period not exceeding 15 days. Therefore, a political control shall be guaranteed about the opportunity to declare such a situation of an exceptional nature and the measures adopted within the fiduciary relationship that shall exist between the Government and the Parliament.

${ }^{38}$ Secondo alcuni la dichiarazione dell'estado de alarma non comporterebbe la sospensione di alcun diritto fondamentale, ma solo la timida possibilità di limitare la libertà di circolazione stabilita (J. N. MuNIZ, Emergencias constitutionales y catástrofes en el ordenamiento constitucional español, in Cuadernos de Derecho Público, 17 2002). Lo estado de excepción, invece, consentirebbe di limitare o sospendere alcune libertà riguardanti la persona, la violabilità dell'abitazione, il segreto delle comunicazioni, la libertà di circolazione e di residenza, di espressione, di informazione, di riunione e di manifestazione; e l'estado de sitio estenderebbe le limitazioni ad un elenco più ampio. Tra gli altri, L. Cotino Hueso, Los derechos fundamentale en tiempos del coronavirus. Régimen general y garantías y especial atención a las restricciones de excepcionalidad ordinaria, in El Cronista; S. De LA Sierra, Confinar el coronavirus. Entre el viejo Derecho sectorial y el Derecho de excepcion, in El Cronista; F. Rodriguez e J. Julio, Cuestiones constitucionales sobre el estado de alarma en España y la pandemia del COVID-19, in IEEE.ES 43/2020, 1.05.2020.

39 See Real Decreto (Roayl Decree) 463/2020. 
territory, extended several times, elicited a heated debate. According to some Scholars, it would have been preferable to call upon the emergency state ${ }^{40}$.

In Germany, the executive power and the administration are today constrained by the respect of the rule of law: the premises to enact the limitation of the rights must be clearly determined ${ }^{41}$. Only the Parliament, with its own law, can allow the government to adopt decisions that affect rights that are constitutionally guaranteed.

There is the general distinction between external states of emergency (states of defence, state of tension) and internal state of emergency, which also includes the pandemic danger and justifies the limitations ex lege to the freedom of movement in the federal territory. To face the health emergency, Germany adopted a series of measures (Corona-Krisenpaket), including the far-reaching package of laws adopted and approved by the Bundestag and the Bundesrat, which imposed some limitations to the individual and economic liberties. Subsequently, the federal government and the länder reached the agreement on the progressive and partial relaxation of the restriction measures to contain the epidemic.

In Romania, more recently, in 2021, a controversy, Terhes v. Romania, has come to the attention of the European Court of Human Rights. Mr. Terhes, a Romania citizen, but also a member of the European Parliament, elected in 2019 for one of the EU Romanian constituencies, lodge a claim against the Romanian Decree which, as the beginning of the first lockdown, in March 2020, provided for restrictions on the exercise of certain fundamental rights, most notably the freedom of movement. Not without a certain degree of speculation, the applicant claimed that this was tantamount to an arrest. More specifically, he had been put in a condition of "administrative detention".

The ECHR dismissed the request, on the basis that, as far as the merit is concerned, the lockdown could not have been equated to a deprivation of liberty, nor to an arrest. He was free to leave his home, albeit for specific reasons, and he could reach different places, "at whatever time of day the situation required". ECHR, application no. 48833/20, decision 20 May 2021, ECHR 159(2021).

${ }^{40}$ Such an interprettion would be warranted by art. 20(1) of the Consolidate Act no. 4/1981, as well as in the Constitutional legal framework existing in Spain: the right of assembly and the right to rally may be suspended exclusively in a "state of exception" (estado de excepción (or de sitio), but not in a state of alert (estado de alarma).

${ }^{41}$ In the past, the state of emergency was mentioned by art. 48 of the Weimar Constitution. This Constitutional Chart prescribed that "when the safety or the public order of the Reich have are seriously affected or prejudiced, the president of the Reich shall adopt measures required to reinstate them, by also adopting, if necessary, the military forces". Among Scholars, see, among the others, K. STERn, Das Staatsrecht der Bundesrepublik Deutschland, 3 voll., München 1977. 
A different approach can be detected in Anglo-American countries, where the application of the martial law is generally rejected, this being understood as a suspension of the ordinary law and temporary government of a country or a part of it through military tribunals ${ }^{42}$. In the other European countries, the debate is still on-going and the development of measures needs to be fully understood.

\section{EMERGENCY, POWER AND FREEDOM “ACROSS THE OCEAN"}

\section{Freedom and limits to public power}

The federal system in the United States entails a multiplicity of centres that exercise the public power, which is characterised by the encouragement of individual freedoms ${ }^{43}$. No particular connections between the central and peripheral government are expected, which may undermine the action of public power in favour of freedom ${ }^{44}$.

In light of the spread of the contagion, the U.S. Department of Health and Human Services (DHS) has played a key role. The public health emergency

${ }^{42}$ On this topic, see A.V. DiCEY, An introduction to the study of the law of the Constitution, 1885, London 1959, 287 ss. This Author refers to a total supremacy of the law. In the United Kingdom, the "Emergency Powers Act 1920", amended in 1964, conferred on the Government the power to issue resolutions, broadly subject to the parliamentary control, when the state of emergency has been declared by the Crown on the assumption that some events have taken place, or are going to take place, and these events are in so far as to deprive the public of what necessary. For the coronavirus emergency, the Coronavirus Act 2020 has been passed. This piece of legislation provides the Government with the necessary powers of emergency. Its impact does not exceed two years for individuals, enterprises and public authorities, and this arranges for economic measures aimed at supporting the "stakeholders [..]". (R. CoRmaCAIN, Coronavirus Bill: A Rule of Law Analysis (Supplementary Report - House of Lords), Bingham Centre for the Rule of Law, British Institute of International and Comparative Law) and supresses human rights (T. KonsTADINIDES E L. MARSONS, Covid-19 and its impact on the constitutional relationship between Government and Parliament, in UK Constitutional Law Association Blog, 26 marzo 2020).

${ }^{43}$ E. Mostacci, COVID vs. Trump, ovvero dell'orchestra che suona da sola, in Federalismi.it., 2020, online. In this contribution, the Author hints also as the faults of the American health system.

${ }^{44}$ The Constitution of the United States of America prescribes that "the privilege or the writ of habeas corpus" shall not be suspended, unless it is necessary for public security in case of riots or invasion (28 USC 2241). The martial law shall not be imposed for a threat of invasion. The necessity shall be actual and current, the invasion effective. Additionally, tribunals and courts shall be shut down and the public sector totally dismissed (ex parte Milligan, 71 U.S. 2, 1866). 
has been declared to contain the transmission ${ }^{45}$ and restrict the freedom of movement of citizens and tourists ${ }^{46}$. People were forced to stay home and to shut down their "nonessential" business by The Emergency Order no. 28 of DHS. The Centres for Disease Control (CDC) ${ }^{47}$ invited the competent authorities - federal, national and local - to draw up the plans for the emergency. The measures adopted by the federal States and local administrations showed a convergent strategy based on the principle of subsidiarity, implementing the demands of civil society.

The adoption by of centralized measures to support economy has followed ${ }^{48}$, whereas the states enacted measures to impede assemblies of people and instruments of moral suasion to reduce social contacts. Despite the commitment in economy by the American government, the general framework has eventually degenerated into clashes between citizens and police forces, these being triggered by social discontent and desperation for the economic conditions of the country.

\section{2. "Safer at Home Order" and its limits}

The Wisconsin Supreme Court's decision 13 May 2020, which ruled on the Emergency Order 28 of the Department of Health Services, can be examined in this light ${ }^{49}$.

The case involves the value of the order of staying home, shutting down unessential business as indicated in the Emergency Order, and the prohibition of travelling. The punishment was imprisonment up to one month, a fine, or both. The "Safer at Home Order", imposed by the executive power, recalls the warning "stay home" that has been adopted in many countries, though in different forms. This judgment has been particularly important in the debate

45 Sect. 319, Public Health Service Act, and 42 U.S. Code $\$ 247 d$.

46 The access to the USA was limited to individuals who were not Americans and who came from affected areas. Additionally, a two week quarantine to citizens and holders of green card who, in the previous 14 days had contact with the affected area, was introduced.

47 This is the Federal Agency, operating at the Department of Health and Human Services, dealing with the protection of health and public security through the detection and prevention of illnesses.

${ }_{48}$ At a central level, the approval of a first financial plan, the Coronavirus Preparedness and Response Supplemental Appropriations Act (CPRSAA), with a commitment of 8,3 billion dollars, after which other measures ensued among which the Families First Coronavirus Response Act and the Coronavirus Aid, Relief and Economic Security Act ("Cares Act") aimed to offer a support to both the economy and the families.

49 Wisconsin Legislature, Secretary-Designee Andrea Palm, 2020 WI 42 of 13 May 2020. The legal provision referred to set forth a criminal sanction in cases of violation, with a 30 day imprisonment and 250 USA dollars of senction. 
on the limitations of rights and individual liberties in democratic countries. Indeed, this leaves room for meditating on the need for justice to preside over public powers in emergency phases. The scrutiny at stake would assure the utmost respect of individual liberties, rights and the interests of the community. This cannot disregard the democratic mechanism, for it is in the storm that rapid action and flexibility are important, these being always achieved in compliance with democratic principles ${ }^{50}$.

The delivery has regarded the administrative measure as "unlawful, invalid, and unenforceable", highlighting a serious legal error. Not only did it have implications for its juridical order, but also for the scope of its general principles, which might result easily permeable in other democratic systems.

The Court points out that the Emergency order 28 is structured as a "general order of general application", a general and abstract act with penal sanctions that can be ascribed to the category of rules, i.e. acts of normative nature $^{51}$. The DHS, instead of following the procedure expected for the rules, would have followed that of orders, and thus trespassed the limits of the powers conferred by the emergency legislation. Such powers are regulatory, although being framed in long time with the delegation to adopt every measure that is necessary ${ }^{52}$.

By this rationale, if the power attributed to the administration includes normative acts, the fact that every necessary measure can be adopted in such long and generic time makes the law unconstitutional. On the contrary, if the power is limited to regulatory acts, the Emergency Order 28 is unconstitutional, because it acquired a normative scope that is not allowed. The Supreme Court applies the principle of the constitutional doubt, which imposes to give priority to the interpretation most compatible with the Constitution. This follows the general principle of the separation and equilibrium

${ }^{50}$ In a similar way, see D. De Lungo, Un atto di coraggio costituzionale. La Corte Suprema del Wisconsin dichiara illegittimo il Safer-at-Home Order, in Diritti comparati, 18.05.2020, as well as in IBL Istituto Bruno Leoni, 27 May 2020, n. 332. The Author maintains the view that the Government cannot replace, with its own decisions, the legislature and, therefore, the democratic circuit of representation. In periods of crisis, Courts cannot indulge in the temptation to replace politics, via an arbitrary system of balance between individual liberties on the one hand, and the interests of the community, on the other hand. By contracts, the judiciary shall guarantee an even more punctual and serious application of the Constitutional framework. Metaphorically speaking, in period of emergency, the power, like Ulysses, shall be wrapped in chains around the mast of the vessel, on order to avoid the deadly and feral songs of the Sirens.

${ }^{51}$ Wis. Stat. $\S \S 227.01$.

52 Of a different opinion, the legal defence of the State Health Secretary, which had always maintained the nature of the Emergency Order 28 as an administrative act, in consideration of the temporary nature of the measure. 
of powers, which aims at preserving the individual liberties. The Court's corollary is that no public liberty is possible if the legislative and executive powers are in the hands of the same authority.

The separation between rules and orders is necessary to ensure the further distinction between the production and application of the law, the first being restricted to the democratic-representative circuit. An unelected technocrat, which in countries such as Italy is perceived as a benefit, given her/his alleged technical competence, is not allowed by Wisconsin's law, nor can the emergency be invoked as exception. It follows that the prolonged state of emergency does not justify the stabilization of the extraordinary power on the part of the government, but it calls for guaranteeing the ordinary democratic channel for political decision-making, secured by the Parliament.

Such considerations go beyond the American context and elicit a further reflection on the Italian experience, where the executive power has gone on to manage the successive stages of the emergency by means of DPCM, with no attempt to rescue the ordinary democratic channel for political decision-making.

\section{The emergency orders caveat}

It is relevant to point out how the Court warns against the risk that the justice might be acquiescent towards government actions in the interest of society, and then recognized as means of oppression. There is no shortage of examples, even in recent history, of exercises of power by the police that, diverging from the Constitutional text, turned out to tread on individual rights. ${ }^{53}$

This issue, which goes beyond the boundaries of the American legislation, concerns the actual capacity of the judicial review of stemming government and institutional abuses in emergency contexts. The Court warns against the risk of developing and implementing a personal view of the common good, the risk of suffering the pressure of public opinion and media, which often become an instrument of dissemination of the government's policy. However, never as in cases of emergency it is necessary to guarantee a strict juridical control. As the Italian Constitutional Court has recently pointed out: "the full implementation of the Constitution requires a coral commitment, with the active and loyal collaboration of all the institutions, including the Parliament, the Governments, the Regions, and the magistrates". Although it does not include a special law for exceptional times ${ }^{54}$, the Italian Constitution offers "the compass to sail on the open sea of the crisis,

${ }_{53}$ Rebecca Grassl Bradley, J. (concurring opinion), § 70.

54 This is quite different from what happens in other Constitutions, such as the Russian one, where art. 56 clearly defines the concept of "necessity". See footnote 19 above. 
starting from the loyal cooperation among the institutions, which projects the solidarity among citizens" 55 .

In view of a full collaboration, the c.d. reason of state cannot be separated from the scrutiny of the strict criteria of interpretation of the fundamental principles of the Constitution. The administrator has to reconcile the interests involved and inform decisions to balance the interests at stake. The political choice governs the assumption of choice between alternatives and, to face the health emergency, the countries opted for different strategies, distempering the constitutional guarantees by means of the principles of proportionality and adequacy.

Yet in no cases - as the Court of Wisconsin has confirmed - the rights and individual liberties guaranteed by the Constitution of a country should disappear in a crisis, not even for public health reasons. The government cannot use the failure of the health system as an expedient to justify the derogation from fundamental rights and liberties. The emergency cannot become source of $\mathrm{law}^{56}$ and affect the other institutional powers, nor can the fundamental rights and liberties be violated. In the highest levels of stress, the Constitution must establish itself as an embankment to guarantee the institutional system and the individual juridical situations. For their part, every democratic country's court can do much to guarantee their protection with due regard for the principles of proportionality and adequacy.

Nevertheless, the interpretation and the very hierarchy of the rights recognized in the Constitution can vary from country to country depending on the specific case. In alike manner, the citizen's sensitivity to the restraint of individual liberties can differ for a number of reasons, and, as the Court of Wisconsin states: "men born to freedom are naturally alert to repel invasion of their liberty by evil-minded rulers".

\section{THE BALANCE BETWEEN FUNDAMENTAL RIGHTS AND LIBERTIES IN DECISA}

\section{On the proportionality of the public health measures}

In Europe the limitations imposed by the emergency measures involved Courts and, in some European countries, were concerned about the freedom of movement, the right to demonstration or assembly. In most cases, the fair balance between the right to health and other fundamental rights has become a core issue.

55 M. CARTABIA, Relazione annuale della Corte costituzionale sul 2019, 28the April 2020, www.cortecostituzionale.it/jsp/consulta/composizione/relazione_annuale.do

${ }^{56}$ Rebecca Grassl Bradley, J. (concurring), § 77: "The Constitution was adopted in a period of grave emergency. Its grants of power to the federal government and its limitations of the power of the States were determined in the light of emergency, and they are not altered by emergency". 
In many countries hit by the pandemic, the political decision to take emergency measures was preceded by the intervention or consultancy of technical-scientific committees, which provided assessments that informed specific political decisions, eliciting a number of questions as to the assumption of liability. ${ }^{57}$

In France, the intervention of the judge of référé can be requested to safeguard the fundamental liberties in case they are violated by legal entities under public law or private legal entities responsible for public services ${ }^{58}$. This is what happened after the adoption of emergency measures, when the judge of the référés of the Conseil d'État ordered the government to lift the ban on assembling in places of worship. The order also entailed measures proportional to health risks and adapted to the c.d. plan of progressive de-confinement, in accordance with the principle: "vivre avec le virus, agir progressivement, adapter localement". ${ }^{59}$

Many associations and individuals brought an action against the décret 11 May 2020, no. 2020-548, which forbid any kind of meeting in religious places, with the exception of funeral ceremonies. These maintained that the ban on assembling in places of worship had to be considered disproportionate to the aim of guaranteeing the public health. The Court also held that it is necessary to avoid any violation of fundamental liberties, as well as discriminating between those who practise a religion and those who do not. The freedom of worship is one of the main principles recognised in the French Constitution of 1958, which testifies French people's fidelity to human rights and the principles of national sovereignty set out in the Constitution of 1789, confirmed and integrated in the preamble to the Constitution of 1946, and to the rights and duties set out in the Chart for the Environment of 2004. This also entails the right to partake ceremonies in public places and must be balanced against the safeguard of health, this being guaranteed too.

The Court examined the forms, modes, including the progressive method, of the measures adopted to guarantee the public health. It held that it would have been possible to adopt less restrictive measures, which allowed the performance of religious ceremonies in complete safety, with due regard of the

${ }^{57}$ Reference can be made to the investigations of the "Crown" or "prosecutor", on the missing inception of a red zone in the Seriana valley in northern Italy at the beginning of the contagion.

58 Art. Law. 512-2 of the French Consolidated Act of administrative justice.

59 Ordonances no. 440366, 440380, 440410, 440531, 440550, 440562, 440563, 440590 of $19^{\text {th }}$ May 2020 . The so called Plan de déconfinement progressif was submitted by the French Government to the National Assembly on 28 April 2020 and it was aimed to lessen, gradually, the containment measures according to criteria different among the 20 Italian Regions. Among new Scholars, see P. Costanzo, Brevi note sulle soluzioni apprestate dalla Francia per contrastare la pandemia nei giudizi di costituzionalità, in Consulta-online, no. 1/2020, 17 April 2020. 
limit to ten people mentioned in the décret no. 2020-584. The general and absolute ban would then be disproportionate to the aim of guaranteeing the public health, since it violates the freedom of conscience and religion, the freedom of movement and meeting. ${ }^{60}$

As known, the freedom of expression and communication, which is the basis of the right to express ideas and opinions collectively, is precious insofar as it is conditional on democracy. It follows that whatsoever interference of its expression must be necessary, adequate and proportional to the objective pursued. ${ }^{61}$ The Conseil d'État enjoins the President of the Council of Ministers to modify the decree above mentioned by implementing measures commensurate with health risks and circumstances applicable to the déeconfinement. ${ }^{62} \mathrm{~A}$ very peculiar case in France is the one concerned about the treatment of confidential data. Since the Government, with a specific law (24 July 2019, no. 2019-774) set up a platform relating to the health data of French citizens, and these pieces of data were dealt with by the Iris subsidiary of an American multinational company, some stakeholders lodge an application with the French competent Court, about the risk of an unwanted export of confidential data outside the EU. Upon some stakeholders lodging a complaint, it was held by the competent Court, the Conseil d'Etat, that the exceptional circumstances justified the set-up of this database, although it is held that by no means could the service provider, fundamentally an American group, to allow the American authorities to have access to data of French citizens ${ }^{63}$.

\section{Freedom of assembly, demonstration and proportionality}

As above mentioned, in Spain the declaration of the estado de alarma elicited a wide debate on the legitimacy of the measures adopted by the government and their implications. ${ }^{64}$

${ }^{60}$ See also the ordonnance 16 October 2020, no. 445102, no. 445186, no. 445224, no. 446225 , about the foreclosure of the sport and leisure centres in the cities of Marseilles and Aix-en-Provences.

${ }^{61}$ Art. 11 of the Declaration of 1789.

62 Previously, on the matter of the strengthening of the powers of the police forces in order both to safeguard the public order during the rallies, and to tackle the violence, the French Conseil Constitutionnel desclared inconstitutional some norms of Law no. 2019290 of 10 April 2019 (so alle loi anti-casseurs): decision 4 April 2019, no. 2019-780. The Court decisum can be found on the website of the Conseil Consitutionel, www.conseil-constitutionnel.fr/decision/2019/2019780DC.htm.

${ }^{63}$ Conseil d'État, ordennance 13 October 2020, no. 444937.

${ }^{64}$ See, among the others, L. Cotino Hueso, Confinamientos, libertad de circulacion $y$ personal, prohibicion de riuniones y actividades y otras restricciones de derechos por la pandemia del Coronavirus, in Diario La Ley, 6 April 2020, no. 9608. E. Arana 
A very interesting case concerned the decision by a Spanish public authority not to allow a demonstration for the first of May, confirmed by the Court of Galicia. ${ }^{65}$ According to the decision, the Real Decreto no. 463/2020 could only have been appealed against before the Constitutional Court, but it did not consider questioning its constitutionality. In the comparative assessment of the rights involved, the Court pointed out that the health risk could justify the appeal to the estado de alarma and the restriction on movement aimed to prevent the spread of the virus. Such measure was thus necessary and proportionate because it regarded the right to life and public health ${ }^{66}$ as a priority.

Before the Tribunal Constitucional the claimant ${ }^{67}$ appealed to the violation of the freedom of assembly in a public place (art. 21 of the Constitution), maintaining that the state of emergency cannot result in the suspension of fundamental rights guaranteed by the Constitution. It requested the adoption of supervision measures whereby the demonstration could be celebrated. ${ }^{68}$

The constitutional judge denied the request endorsing the priority of the right to life and health in view of the emergency ${ }^{69}$ It has been highlighted that public authorities can act the right to meet and demonstrate by modifying the circumstances of their performance, banning or limiting them in case of sound reasons, such as the alteration of public order with damages to people or goods, or the damaging of other constitutional values. ${ }^{70}$

Garcìa, Covid 19 y Derecho Público en España: el virus que desnudó nuestro, in Diritto pubblico dell'economia, 17th May 2020.

${ }^{65}$ Tribunal Superiore de Justicia of Galicia, Sala de lo contencioso-administrativo, Section no. 1, Court decision, 28 April 2020, no. 136. Among Scholars, L. Cotino Hueso, La posible constitutionalidad de las manifestaciones bajo ed Covid 19 y el Decreto para el Tribunal Constitutional, in www.derechocovid.com/ del 01 maggio 2020.

${ }^{66}$ Art. 43, paragraph 2, Spanish Constitution.

${ }^{67}$ It is an individual application (so called amparo claim), which in Spanish law allows the citizen to directly raise proceedings before the constitutional Court to ultimately claim the protection of fundamental rights affected by any conduct of the public powers. For a commentary, see F. Marconi, Crisi Covid e limitazione della libertà di movimento, del diritto di riunione e di manifestazione in Francia, Spagna e Germania alla luce della giurisprudenza recente, in Giustamm, giugno 2020.

${ }_{68}$ The "Constitutional case law" previously clarified that the right of assemply and the right to rally represent a collective form of freedom of expression. Such a freedom is exercised through a temporary gathering of individuals, who behave specifically to allow (i) the exchange and expression of ideas, (ii) the protection of interests or (iii) the publicity of issues or claims (Tribunal Constitucional de España, Sent. 85/1988, in BOE n. 128, de 28 de mayo de 1988).

69 The Court highlights that the expression could not have taken place in a different date and the adoption of precautionary measures would have made useless a subsequent declaration on both the procedure and the merit.

${ }^{70}$ Exclusively in case of emergency and on the basis of art. 22 of Law no. 4/1981, it is possible to put on hold art. 21 of the Spanish Constitution and to require either the assem- 
The denial was motivated by the available information about the virus and the lack of certain scientific estimates of its consequences. ${ }^{71}$ It was the logic and necessary response to slow down the pandemic, whose high rate of infection could have caused the public health services to collapse..$^{72}$

Under no circumstances did the decision take account of analogous situations, where other local Tribunals adopted different positions. It is the case of the superior tribunal of the autonomous community of Aragona, which authorised some meetings in view of the first of May, maintaining that the estado de alarma can limit but not suspend the right of assembly demonstration. $^{73}$ The very Ministerio Fiscal of Spain affirmed that the state of emergency does not limit the right of assembly, allowing its course under the control of the health authority. ${ }^{74}$ This shows that the debate on emergency measures is still open in Spain, with a number of important implications.

\section{The use of principles of proportionality and adequacy in Germany}

In Germany the fundamental rights are guaranteed by the artt. 1-19 of the fundamental law. In case of violation, it is possible to ask the ordinary tribunals or the federal constitutional Court (Bundesverfassungsgericht). ${ }^{75}$

blies or the gatherings to the subject to previous authorisation. Additionally, they could be prohibited since the beginning, or, if already started, they could be terminated in advance.

${ }^{71}$ The denial of authorisation of the rally would have been based on the need for safeguarding both the life and the physical integrity of the individuals (art. 15 Cost.) and the protection of the health (art. 43 Cost.).

${ }^{72}$ In cogitating on the principle of proportionality, the Tribunal reminds of the fact that the organisers of the rally had not arranged for the adoption of specific measures to keep at bay the transmission of the virus, nor to reduce the concentration of vehicles following up on the massive adherence to the initiative.

73 Tribunal Superior de Justicia de Aragon, Section no. 1 loaf the Sala de lo contencioso-administrativo, Court decision 30 April 2020, no. 151. The public sector authorised a rally with a maximum of 60 vehicles and just one person withing each vehicle. The Court held that a case-by-case assessment was necessary, and this assessment needed to take into account the measures that practically would be adopted in order to reduce the risks for the health.

${ }^{74}$ Contraris Departament d'Interior de la Generalitat de Catalunya before the Tribunal Superior de Justicia de Catalunya, Section no. 2 of the Sala de lo contencioso-administrativo, 24 April 2020, no. 1223, in connection with an application put forward against the rejection of the request of authorisation for a rally in Parque de la Ciutadella de Barcelona before the Parliament of Catalunya. It was held that the right of assembly cannot be exercised, while the state of alarm is still in place.

${ }^{75}$ For a view on some decisa, reference is made to some press releases, namely the one of 7 April 2020 www.bundesverfassungsgericht.de/SharedDocs/Pressemitteilungen/ EN/2020/bvg20-023.html, of 14th May 2020, both bearing declarations of procedural rejection of the applications against the postponement or the relaxation of the containement measures for the pandemic, www.bundesverfassungsgericht.de/SharedDocs/Pressemit- 
This has recently ruled on an appeal against the measures adopted by the city of Stuttgart, which forbade assemblies and demonstrations while respecting social distancing. ${ }^{76}$ It has clarified that, according to the German fundamental law (art. 8, co. 2), the law can only limit assemblies in public spaces. Legit limitations must be aimed to protect goods of the same weight, or under the guarantee of the test of proportionality. ${ }^{77}$ The authority is always expected to examine the criteria of each case, ultimately to assess whether it is possible to find alternative ways consistent with the exercise of the constitutional right.

Another recent case has concerned a pre-court appeal against the emergency measures adopted by the city of Giessen, which forbade some assemblies and demonstrations ${ }^{78}$. The federal judge allowed the administration to decide again on the issue, since an erroneous interpretation of the Land Assia for the fight against Covid19 had occurred. This did not count as an absolute ban on demonstrations, but rather a temporary prohibition if the circumstances allow an adequate level of protection of public health. ${ }^{79}$

Once again, the judgment of careful balance between fundamental rights and freedoms requires the application of the principles of proportionality and adequacy in the assessment of the single case and the elements that are necessary to form a judgment.

In a different case concerning the ban on assemblies in places of worship, ${ }^{80}$ the Court rejected the motion after a careful analysis and comparison

teilungen/DE/2020/bvg20-036.html. Among Scholars, see, ex plurimis, A. DE PETRIS, Un approccio diverso: l'emergenza "collaborativa" del federalismo tedesco, in Osservatorio costituzionale AIC, no. 3/2020, 2020.

${ }^{76}$ Application against the decisions adopted by the Administrative Tribunal of Stutgard and the competent appeal Court, the Administrative Court of the Land of Baden-Württemberg, Federal Administrative Constitutional Tribunal, decree 14 April 2020 (1 BvQ 37/20).

77 The freedom of assembly is a right acknowledged by art. 8 of the "Fundamental German law", where it is recognised that all German people are entitled to assembly, ss long as this is done freely and without weapons. A previous notice is not required, nor an ad hoc authorisation; the right may be fettered by law, as far as outdoor assemblies are concerned.

${ }^{78}$ Federal Constitutional Tribunal, ordinance 15 April 2020, 1 BvR 828/20. On first instance, the emergency measures adopted ware later confirmed by the Giessen Administrative Tribunal and by the Administrative Court of the Assia Land. Further decisa by the Federal Constitutional Court elate to the rallies organised in Berlin, against the Government measures relating to the pandemic. See ordinance of 29 August 2020 (1 BvR 2038/20, 1 BvR 2039/20, 1 BvR 93/20). Yje Federal Constitutional Tribunal dismissed any application.

79 To confirm this, it is worth mentioning that the "decree" of the Assia Land Government reserved to the competent Authorities a discretionary power, as well as a further assessment of the actual circumstances where the rally should have taken place.

${ }^{80}$ Ordinance $1 \mathrm{BvQ} 28 / 20$ of 10 April 2020 whereby it was required to cancel the decision of the Assia Administrative Tribunal, in addition to the suspension of the prohi- 
between the interests involved (freedom of religion, freedom of assembly in places of worship, ${ }^{81}$ right to public health ${ }^{82}$ ). The appellant had considered the celebration of the Eucharist as a key component of the faith, whose lack cannot be outweighed by other forms of religious activity ${ }^{83}$ and further regarded the prohibition of celebration as a serious interference with the freedom of faith and religious belief. ${ }^{84}$

In this case, the Bundesverfassungsgericht confirmed the priority of public health, although in the German system the boundaries of the law are outlined by the contestant legislation of the federation and the States, and the German law does not contain any mention to the right to health comparable to the art. 32 of the Italian Constitution.

However, the potential assemblies in places of worship could have increased the risk of contagion, driving the health structures to the brink of collapse.$^{85}$ It has been maintained that the protection of life and physical safety had to prevail on the fundamental freedom of worship. The Court's analysis and balance mirrored the particular phase of development of the contagion in the country.

The decision thus recognises the need of developing the judgment of proportionality of the measures adopted through a careful analysis of the conditions and elements of assessment. The judgment is anchored to these with due regard of the principles of proportionality and adequacy. In order to define the grade of limitation of individual liberties, a rigorous examination of each case's circumstances is necessary.

\section{The use of principles of precaution and loyal collaboration in Italy}

The above-mentioned case law joins one to reflect on the Italian experience, also in the light of the peculiarity of each single legal system. In Italy,

bition of assembly in churches, mosques, synagogue, and to take part in assemblies of other religious groups.

81 Art. 4 of the "German Fundamental Law".

${ }^{82}$ As far as this matteri is concerned, see M. CARRER, Tutela della salute e dimensione della discrezionalità a livello comparato: l'esperienza tedesca, in La tutela della salute tra tecnica e potere amministrativo, M. Andreis (ed), Giuffrè Editore, 2006. According to this Author, a purposive reading of the first three articles of the "German Fundamental Law", in conjunction with artt. 19, 20 and 74 GG, allows to justify, constitutionally, the German right to health.

${ }_{83}$ The Vatican Council II, Dogmatic Constitution on the Church, no. 11, as well as the Catechism of the Catholic Church, no. 1324-1327.

${ }^{84}$ Art. 4, paragraph 1 and 2, "German Fundamental Law".

${ }^{85}$ In order to corroborate such stances, reference is made to the risk assessment carried out by the Robert Koch Institute as of 26 March 2020. 
the Government decided to centralise the assessment in the Covid-19 driven matters in terms of balance between rights and liberties. By doing so, it adopted emergency measures, which prevailed on the autonomy of local administrations.

This was the strategy during the most acute phase of the contagion (c.d. phase 1), which went through DPCMs, without diversifying the action depending on the level of contagion in the single territory. A sole "red zone" was outlined, in which travels from the north to the south of the country were allowed to a degree. Some rights and liberties were suspended, while the assessment of proportionality in the exercise of power has often proven to be inadequate. The management of the c.d. phase 2 followed a similar strategy, when the tension between regions rose, and some of them tried to limit the restrictions in view of the change of conditions and elements of assessment. This happened, for instance, based on the order of the President of the Region Calabria, which allowed cafes, pastry shops, restaurants, and farmhouses to resume their business guaranteeing service through outdoor tables, ${ }^{86}$ against which the Prime's Minister Office appealed with success ${ }^{87}$. The Regional Administrative Court of Calabria, considering the multiple public and private interests at stake, held that the administrative judge could not determine the content of administrative measures. ${ }^{88}$ Based on this, the order of the Region de facto against the central Government decision, was cancelled.

The Court's line of reasoning does not refer to any "balance" between fundamental rights and liberties, nor does it properly consider the interests involved, but rather states that the freedom of economic initiative (art. 41, Italian Constitution) cannot be performed at the risk of damaging human security. Furthermore, as far as limits to the activity of a business person, there is no reserve of legislation, and therefore caveats to the entrepreneurial activity can be then introduced also by a mere administrative act, rather than by law.

A controversy of a similar nature, where a contrast between central power and local one emerged in Italy, is the one happened in Messina, the Sicilian city lying at the "gate" of the Mediterranean island, through whose sea-port thousands of vans and cars, carrying goods, pass though on daily basis. On 5 April 2020 , three weeks after the start of the lockdown, the local mayor, concerned about the quantity of people arriving via ferry from the opposite continental

${ }^{86}$ Ordinance 29 April 2020, no. 37, referring to further measures for the prevention and management of the COVID-2019 epidemiological emergency.

87 Tar Calabria Administrative Tribunal (or "Tar"), section 1, Italian Government v. Calabria Region, no. 00841/2020.

88 This approach is radically different from the one adopted by the Wisconsin Court in the case above analysed. 
coast of Calabria, just 5 kilometres east of the city, attempted to impose a system whereby, each individual who wanted to enter the city, needed to register with a Covid test, aimed to prove that he/she was not affected by Covid. Merely to contextualise the matter, it is worth recalling that at that time Sicily and more in general southern Italy were not Covid-affected areas, since the real tragedy, with thousands of casualties, was taking place in Northern Italy. The decreed of the Messina mayor was aimed to discourage people, particularly those originally from Sicily but living in northern Italy, from coming back to their places of origin, as the reunion with the relatives could have caused a deadly contagion in an area that, at that time, albeit in the heavily affected Italy, was basically immune from the problem. Against the decision of the Mayor, the President of the Ministers' Council raised a claim, for which, according to the Italian Constitutional rules, a previous opinion of the Consiglio di Stato, the highest administrative judiciary body in Italy, was required. With an opinion 13 May 2021, no. 850, this Court held that, given the national nature of the emergency, a unitary and holistic management of the health crisis was necessary, even though there must be great respect for the Region and local bodies, which are constitutionally protected. In essence, regional or local "interferences", such as the one of the Mayor of Messina, would affect the complex strategy of the management of the emergency, particularly in cases where some constitutional freedoms would have been affected. In this case, the unnecessary checked required by the mayor of Messina would have affected the right of free initiative, pursuant to art. 42 of the Italian Constitution.

A confirmation of this, in what can be defined the "love-hate relationship" existing between the Italian central power, and its 20 regions, is evidenced by the "interim order" whereby the Italian Constitutional Court, on 24 February $2021^{89}$, upon appeal by the Government, held that the management of the pandemic did not belong to the local authorities. In this specific case, the Constitutional Court challenged a law passed by a Region, Valle d'Aosta, in the far north-west of the country, at the border with Switzerland and France. This local piece of legislation was aimed at "governing" the pandemic at a local level, with a very high level of autonomy, and in contrast with certain legal provisions of the Central State, given that fact that the pandemic is a global matter, going beyond the national borders. It is implied, in this Court decision, that a global issue like the pandemic may have an impact on the same sovereignty of the country. Therefore, the central State, rather than the Region, need be in charge of. The dictum ${ }^{90}$ is even more important, since the

${ }^{89}$ Italian Constitutional Court, interim decision (ordinanza) no. 4 of $24^{\text {th }}$ February 2021.

${ }^{90}$ For a commentary on such a Court decision, see C. Della Giustina, "Le Dinamiche del Regionalismo durante l'emergenza Sanitaria da Covid-19 dinanzi alla Corte Costituzionale. Nota a Corte Costituzionale 12 marzo 2021, no. 37" (2021)2 Gazzetta Forense 333-345. 
Region at stake is one of the Italian five ones, enjoying a higher degree of autonomy. This does not justify, though, the promulgation of any law in the area of the global matter of the pandemic.

The central power to identify the necessary measures would be justified by the principle of subsidiarity, which imposes that, in case of international emergency, precautionary measures at identified at unitary administrative level ${ }^{11}$ and that the State keeps the legislative competence in the field of health and civil protection. Had this been the case, the State would have not performed a fall-back power, but rather "the call-back of administrative functions in reason of the principle of subsidiarity[..]"92.

No mention of the principle of proportionality and adequacy regarding the specific case is made. In its place, the principle of precaution is invoked. This has to guide public powers in a health emergency on which, the Tribunal highlights, there are no certainties. Fear feeds on uncertainty, and every measure appears proportionate to the aim of preventing the collapse of the national health system, turning the action of public powers into forms of prevention of the same scientific knowledge.

In fact, there are stances in Italy ${ }^{93}$ where it is advocated that the circulation of the virus should have required the activation of the precautionary principle ${ }^{94}$, rather than the emergency powers. More precisely, it is

${ }_{91}$ Art. 118, paragraph 1, Italian Constitution.

${ }^{92}$ It must be observed that art. 41, Italian Constitution, in recognising the freedom of economic initiative, prescribes that such an initiative cannot be exercised in a way to damage the safety, the freedom, the human dignity. Since there is no law reserve as regards the requirements, or limits, to be imposed on businesses, such requirements may be imposed also with the decision of an administrative nature, and this has been achieved with the decree of the President of the Ministers' Council.

93 L. R. Perfetti, Sullo statuto costituzionale dell'emergenza. Ancora sul diritto pubblico come violenza o come funzione dei diritti della persona, in P.A. Persona e Amministrazione, no. 2/2020, pp. 51-79.

94 The precautionary principle represents the ordinary tool in order to manage the risk, by risk meaning the one characterised by scientific or technical uncertainty. This is typical of the right to health, or the financial risk. N. IRTI, E. SEVERINo, Dialogo su diritto e tecnica, Roma-Bari, Laterza, 2001. G. MANFREDI, Cambiamenti climatici e principio di precauzione, in Riv. Quadr. Dir. Ambiente, 2011, p. 27. M. PASsalacQua, Diritto del rischio nei mercati finanziari: prevenzione, precauzione ed emergenza, Padova, Cedam, 2012. F. De LeONARDIS, Il principio di precauzione nell'amministrazione di rischio, Milano, Giuffrè, 2005. A. BARONE, Il diritto del rischio, Milano Giuffrè, 2006. In respect of the precaution, emphasis has been placed on the fact that there is a steady consolidation of the precaution as a rule so that it engenders a so called right to scare. C. R. Sunstein, Laws of Fear: Beyond the Precautionary Principle, Cambridge, Cambridge University Press, 2005. C. R. Sunstein, Can It Happen Here? Authoritarianism in America, New York, Dey Street, 2018. Furthermore, it has been highlighted that "some accounts of 
maintained that, since the declarations of the World Health Organisation encompassed expressions such as recommendations to the international community and they asked for the adoption of the adequate measures, this wording should have required, as a consequence, the set-up of measures aimed to prevent the contagion, in order to provide each health organisation, worldwide, with tools, machines, and necessary staff. However, by no means did this wording hint at the need for giving an extraordinary power.

In this perspective, the prior objective that prevails on fundamental rights and liberties is not the protection of the right to health, but to prevent the hospitals' wards from being mobbed and overwhelmed. However, by invoking the right to health, surgical operations and medical examinations are thus cancelled, and thousands of citizens with no insurance will renounce

counterterrorism law and policy after 9/I1 decry the use of 'extraordinary' military institutional forms and devices, such as military commissions and Combatant Status Review Tribunals, and argue that executive and administrative counterterrorism actions should be channelled through the ordinary administrative law. It is sometimes implicit, and sometimes explicit, in these accounts that the ordinary administrative law is less deferential to executive and administrative bodies. For some civil libertarians, military processes operate largely in a legal black hole, while ordinary administrative law embodies the thick rule of law. But these accounts rest on a mistaken premise - that the ordinary administrative law is indeed relatively less deferential to executive or administrative action. That is a plausible view about normal times, when judges reviewing the EPA's latest technical rulemaking or whatnot dial up the intensity of arbitrary and capricious review, review under Chevron and Mead, and so forth. But where judges perceive an emergency, or merely fear thwarting administrative action that might be necessary in an emergency (even if the judges are sceptical that an emergency really exists), the parameters are adjusted downwards; standards of rationality, statutory clarity, evidence, and reasonableness all become more capacious and forgiving. If administrative law itself contains a series of potential grey holes, the operational differences between the military model and the administrative law model are at least smaller than the critics assume, and in times of perceived emergency will tend not to exist at all". A. Vermeule, Our Schmittian Administrative Law, in Harward Law Review, vol. 122, no. 4/2009, p. 1139.

As far as the health emergency is concerned, some Scholars maintain the view that there are "symptoms of a dangerous trend towards a state of prevention - which can be interpreted as one of the possible operational modes of the state of exception - can be clearly found in the replacement of the general request of freedom with the one of authority, whose consequences consists of a general and (for a long time) absolute limitation of constitutional rights, in the 'concession' of glimpses of freedom by the same public power, in the achievement of a condition of general surveillance by the police forces to which the entire national community is subject. This corresponds, by all means and in a coherent way, to the functional 'logic' of the prevention which relates to the contrast, to the abstract and hypothetical risk and to which, therefore, the inexistence of limits to the achievement of an ideal scope pertains". V. BALDINI, Proporzionalità e adeguatezza versus prevenzione nel controllo di razionalità delle misure di contrasto all'emergenza sanitaria: tra premesse di metodo e percezioni esegetiche, in DirittiFondamentali.it, fasc. 1/2021, p. 145. 
to the prevention of important diseases, risking their life. As to this second aspect, there cannot be any answer to the question, as these causalities will seemingly never be mentioned in Civil Protection's bulletin.

In a similar manner, in the name of the potential damage to human security, the freedom of economic initiative was limited and the order of the Region Calabria was cancelled. The President of the Region was charged with an excess of "v" $\beta \rho 1 \varsigma$ "95, "ubris" in the transliteration from Ancient Greek, and reported to have violated the principle of loyal collaboration between the subjects of the Italian Republic. Clearly, this is a different way of considering the loyal collaboration invoked by the Constitutional Court, which does not impose a one-way direction (from the lower level of administrations to the top), but it is inspired by the principle of subsidiarity referred to in Article 5 of the EU Treaty ${ }^{96}$.

In Italy the principles of precaution and loyal collaboration prevail on those of proportionality and adequacy of the assessment of measures, therefore one wonders whether European citizens enjoy the same rights, freedoms and forms of protection.

Where are the "constitutional traditions common to the Member States of the European Union" 97 "?

In this scenario, it is pretty understandable, in light of such different attitudes, to assess whether the Union is still a valuable idea for the people who are part of it. It would be more consistent with the idea of Europe a formal and substantial recognition of common rights and liberties in terms of

${ }^{95}$ In Ancient Greece, those who refused to acknowledge the powers of the Gods, committed a sin, the $\tilde{\beta} \beta \rho 1 \varsigma$, the brazen arrogance which manifests itself when one demands to overcome the limits imposed by the nature, by the destiny or by the law. On this topic, see among others G. Reale, Platone, apologia di Socrate, Bompiani, 2000.

96 As well known, the subsidiarity principle under art. 5 of the Treaty of the European Union is aimed to guarantee that the decisions are adopted in a way that it is as much as possible close to the citizen. The actual collaboration has been recently recalled in the annual report of the Italian Constitutional Court. See M. CARTABIA, Relazione annuale della Corte costituzionale sul 2019, 28 April 2020 (www.cortecostituzionale.it/jsp/consulta/composizione/relazione_annuale.do)

${ }_{97}$ Needless to say, this is a broad statement, conceived by the Court of Justice of the European Union, later encapsulated in the Treaty of the European Union, as well as the Chart of the Fundamental Rights of the European Union. The first mention can be found in the case of Court of Justice, Internationale Handlesgesellschaft (CJEU, Court decision 17 December 1970, controversy 11/70), relating to the conflict between the norms of the Union and the legal system of each Member State. Starting from then, the Court of Justice of the European Union focused on the matter to offer protection of the fundamental rights within the European Union, whereas in the past this fell within the exclusive remit of the "internal", therefore national, Courts. For a commentary, see S. CASSESE, The Constitutional Traditions Common to the Member States of the EU, Il Diritto dell'Economia, no. 4/2017. 
interpretation and application, instead of the multifarious interpretations arising out of national Courts.

As the Court of justice has clarified since the international case "Handlesgesellschaft", the protection of fundamental rights is part of the general juridical principles whose adherence is guaranteed by the Court. The safeguard of these rights, while being informed to the constitutional traditions common to the Member States, must be guaranteed within the structure and aims of the Community, and today of the Union ${ }^{98}$. The case inaugurates a line of decisions in which the Court shall guarantee the rights that are part of the constitutional traditions common to the Member States, and, above all, the fundamental rights of the person.

If it is true that the force of the constitutional traditions lies in the Court of Justice of the European Union, being in fact the product of its activity ${ }^{99}$, this should respond to the emergency and mend fences, at least enforcing compliance with the principle of proportionality. The aim is that of preserving the major objective of the Treaty of the European Union, namely the creation of an increasing unification among European peoples ${ }^{100}$, which has never meant to be an alternative to national identity ${ }^{101}$.

In an era that is likely to resemble Hegel's dark night ${ }^{102}$, the Europe and its citizens need more than ever the general principles of the Union law on which to base the democracy of the measures, to regain confidence in a common project with sound bases in the fundamental rights and freedoms.

${ }^{98}$ CJEU, Court decision 17 December 1970, controversy 11/70 cited, point 4 of the legal motivation.

${ }^{99}$ Among Scholars, see B. DAves, Internationale Handelsgesellschaft and the miscalculation at the inception of the ECJ's Human Rights Jurisprudence, EU Law, Cambridge, 2017; F. Belvisi, The Common Constitutional traditions and the Integration of the EU, First European Socio-Legal conference on European Ways of Law, Onati, 2005.

100 Art. 1, paragraph 2, TEU.

101 Art. 4, paragraph 2, TEU, stipulates as follows: "The Union shall respect the equality of Member States before the Treaties as well as their national identities, inherent in their fundamental structures, political and constitutional, inclusive of regional and local self-government. It shall respect their essential State functions, including ensuring the territorial integrity of the State, maintaining law and order and safeguarding national security. In particular, national security remains the sole responsibility of each Member State".

102 The reference here is to the famous expression used by Hegel in the Premise to the Phenomenology of the Spirit (F. Heghel, Phänomenologie des Geistes, 1807). The citation "the night of the black cows" turns up in a section where Hegel argues with Schelling as regards the concept of absolute, to be regarded as "absolute identity with himself". He wanted to refer to all the concepts whereby the reality is interpreted as different from the "one" where we live. 


\section{THE ECONOMIC AND FINANCIAL RECOVERY PLANS IN SOME EU COUNTRIES}

As well known, in response to the health crisis arising out of the Covid-19 spread, the European Union has arranged for a 750 billion Eurofinancial package, made up of at least $50 \%$ of subsidies, within the Next Generation EU (or, shortly, NGEU) programme. ${ }^{103}$ The purpose of the package is to encourage the post-pandemic recovery ${ }^{104}$, also with emphasis placed on the sustainability. ${ }^{105}$

The main part of the NGEU programme is the Recovery and Resilience Facility (briefly, RRF), which lasts six years, from 2021 until 2026, with a global dimension of 672,5 billion euro (mainly subsidies, amounting to 312,5 , with the remaining 360 billion loans at a beneficial interest rate).

In Italy, the Recovery and Resilience National Plan (PNRR, in the Italian acronym) is integral and quintessential part of this programme.

The PNRR submitted by Italy is hinged upon investments, as well as a coherent package of reforms, where an amount of 191,5 billion euros of allocated resources. These resources are funded via the PNRR and, as far as the 30,6 billions are concerned, via an ancillary fund, set up by Legislative Decree 6 May 2021, no. 59. The latter is pegged to the multiannual variation of the public balance sheet approved by the Ministers' Council on 15 April 2021. The total of expected funds is tantamount to 222,1 billion.

Additionally, by 2032, additional funds have been budgeted. Equal to 26 billion Euros. These funds are aimed to implement ad hoc projects, but also to fill in the gaps of resources of the Fondo Sviluppo e Coesione (therefore, the Development and Cohesion Fund) All in all, Italy will be able to rely on 248 billion euros. Additional resources are the ones made available by the REACT-EU programme which, as set forth in the EU regulation, will be utilised in the 2021-2023 years. These additional resources are tantamount to 13 billions ${ }^{106}$.

${ }^{103}$ O. Picek, "Spillover from Next Generation EU" (2020)55 Intereconomics 325-331.

104 M. Lopriore, M. Vlachodimitropoulou, Recovery and Resilience Plans for the Next Generation EU: a Unique Opportunity that Must be taken Quickly, and Carefully, EIPA Paper, 2021, online.

105 E. Palacková, “Two Birds with One Stone: Greening the EU's Post-Coronavirus Recovery" (2020)19 The European View 138-145; B. De Witte, “The European Union's COVID-19 Recovery Plan: the Legal Engineering of an Economic Policy Shift" (2021)58 Common Market Law Review 635-689; J. Echebarria Fernández, “A critical Analysis on the European Union's Measures to Overcome the Economic Impact of the COVID-19 Pandemic" (2020)3 European Papers 1399-1423; C. Vielledent, J.F. Drevet, The European Economic Recovery Plan, a Historic Breakthrough. Sustainability without Funding is Unsustainable" (2021)441 Futuribles 85-94.

${ }^{106}$ Ministry of Economy and Finance, official website. 
The Plan evolves across three fundamental, strategic pillars, also in this case fixed by the EU. Ultimately, this initiative is purported to remedy the economic and social damages of the pandemic crisis. Additionally, it contributes to solve the structural weaknesses of the Italian economy and to guide Italy through a process of environmental and green change.

Furthermore, the plan envisages a very ambitious set of future reforms, to ensure that the implementation phase of the same plan be facilitated. More in general, the plan should, on the one hand, contribute to the modernisation of Italy, on the other hand, make the prospective post-pandemic economic context instrumental in the development of the business activity.

To such an end, some activities are promoted, the purpose of which is to promote the competition as a tool whereby both the social cohesion and the economic development, as well as the simplification of the public sector, are safeguarded.

The section relating to the required reforms of the public sector envisages measures aimed at the public contracts. More in detail, it starts off from the assumption according to which to simplify the norms relating to the public procurement and administrative concessions, is essential target to ensure that efficient infrastructures are implemented, and the building sector be back on track again.

In fact, the latter are regarded as essential features in order to launch again the post-Covid 19 national economy. These plans of so-called simplification aim to make less complex the process of outsourcing. However, they also look at the phases of both planning and projects, where the public sector usually identifies the needs of the relevant community ${ }^{107}$.

In order to implement such legal provisions, ad hoc regulation has been passed as a matter of urgency in the area of the public contracts. This body of law will be beefed up by the process of simplification already approved in 2020, based on the Law Decree 16 July 2020 no. 76 (so called "Simplification Decree"), also mercy of a postponement of the effectiveness of some of the legal provisions encompassed therewith.

It is worth noting that Law 29 July 2021, no. 108, in converting in law Decree no. 77 of 2021, confirms the relevant structure of the latter, although it has ended up increasing the number of the relevant articles. The Decree at stake is defined Simplification Bis, which means in English Simplification II, therefore Simplification Decree II, since it has been passed on the wake of the Simplification Decree and with the specific purpose to simplify, among others, the outsourcing process of contracts relating to the same implementation

${ }^{107}$ As inferable from the section of the reform relating to the public sector and, in detail, the "Riforme abilitanti: semplificazione e concorrenza" ("Qualifying reforms: simplifications and competition) of the PNRR. 
of the works and activities encompassed with the PNRR. The ultimate goal of this is to speed up the timeframe of implementation of the works, although the "Genoa Model", which was totally in derogation from the "basic law", has not been adopted. ${ }^{108}$

The piece of legislation at stake is made up of two sections: the first one (articles from 1 to 16) is concerned about the governance and management of the PNRR interventions. This section governs the system of coordination, management, implementation, monitoring and auditing of such interventions (Title I). Additionally, it contains a definition (i) of the fall-back powers in cases where the local authorities did not comply with the obligations and commitments aimed to implement the PNRR, (ii) of the procedures aimed at overcoming the dissent and of those concerned with the financial management of the relevant resources (Title II).

By contrast, in the second section there are, duly incapsulated, legal provisions of acceleration and simplification of the procedures and those whereby the administrative capacity is strengthened: environmental transition, acceleration of the environmental and landscape process (artt. 17-37 quater); digital transition; (artt. 38-43); special procedure for some PNRR projects (artt. 44-46); public contracts (artt. 47-56 quater); simplification in the investments and interventions in Southern Italy (artt. 57-60 bis); amendments to Law 7 Augost 1990, no. 241 (artt. 61-63 bis); further measures the administrative capacity is strengthened (artt. 64-67).

The Simplification Decree II is connected with, particularly, the process of award procedures. For contracts which are worth either more or less the specific thresholds identified by the EU bodies, from time to time, the recent novelties purport to "encourage the public investments in the infrastructures and public services sector, as well as in order to better cope with the economic, negative consequences of the Covid-19 containment and global emergency ${ }^{109 "}$.

Ultimately, the Decree at stake show-cases significant and, to a certain extent, "revolutionary" measures of simplification of the procedures whereby works, services and provisions of services are outsourced. As a result of this, the timeframe of the bidding auction will end up being reduced. Similarly, the timeframe of the competitive bidding process

${ }_{108}$ In the 2018 collapse of the motorway bridge in Genoa, which causes several casualties, the way the bridge was rebuilt complied with a process where, to ensure that a new bridge be available soon, the entire Italian procurement legislation was derogated. In respect of this matter, including the "constitutional" impact of this ad hoc legislation, see in Italian C. Della Giustina, Il decreto-Genova al vaglio della Corte costituzionale, in CamminoDiritto, 2021, online.

109 Our translation from the Italian. 
should result in being optimised. Likewise, the bidding activity of the businesses, at the moment very burdensome and complex, should turn out to be optimised $^{110}$.

In Spain, as a result of the pandemic, a Recovery, Transformation and Resilience Plan has been passed by the Spanish Government in October 2020 , in response to the health crisis and, therefore, the economic crisis of a global nature. The gigantic number of financial resources addressed to the different countries, including Spain, will be a unique opportunity for the Hispanic nation to develop an economy of a different nature: digital and technological ${ }^{111}$; green ${ }^{112}$. Further goals, as a result of these strategic achievements, would be the creation and competitiveness of companies. Ultimately, the Recovery, Transformation and Resilience Plan in Spain "will entail a significant volume of public and private investment in the coming years" 113 .

In France too, a plan, called in English "National Recovery and Resilience Plan of France", has been drafted and it is based on investments, whose funding will originate from the Recovery and Resilience Facility, for at least Euro 40 billion. The investments have been spelled out in writing by the French Prime Minister, on $3^{\text {rd }}$ September 2020. The National Recovery and Resilience plan is based on the environment, he competitiveness, and the social and territorial cohesion. This latest category encompasses, among others, "job preservation, young people, persons with disabilities, vocational training".

As far as Germany is concerned, the Germany's recovery and resilience plan, approved by the EU Commission in 2021, will use the Euro 25.6 billion via a German Recovery and Resilience Facility.

110 This activity may potentially reflect on the same way the Government operates. This is due to the fact that there will no longer be room for negotiations, nor for compromises, given the fact that a governmental action will be already fixed in its goals. See in Italian, Cassese, Il cambio di metodo. Doverosi passaggi di governo, Il Corriere della Sera, 19 June 2021; A. Sciortino, PNNR e rilfessi sulla forma di governo italiana. Un ritorno all'indirizzo politico «(normativo»? (2021)18 Federalismi.it 235-261.

${ }^{111}$ In turn, this will accelerate "the productivity, skills and connectivity of the entire population" (Presidency of the Government of Spain, Recovery, Transformation and Resilience Plan, Madrid, October 2020, p. 10)

${ }_{112}$ As far as this aspect if concerned, the goal of the Spanish Resilience plan is based on the "protection and conservation of the wealth of its natural goods as sustainable assets for its territories and a fundamental element in tackling climate challenges" (Presidency of the Government of Spain, Recovery, Transformation and Resilience Plan, cit. p. 10).

113 Presidency of the Government of Spain, Recovery, Transformation and Resilience Plan, Madrid, October 2020, p. 12. 
The German Recovery and Resilience Plan ${ }^{114}$ is, fundamentally, hinged upon the green and digital transition ${ }^{115}$, with no less than $42 \%$ of its total allocation to measures, aimed at climate objectives. Among the different measures, mention must be made to the "decarbonisation" of the industry, with ensuing emphasis on the renewable hydrogen, investments in sustainable mobility, and the renovation of residential buildings to improve their energy efficiency.

Furthermore, at least $52 \%$ of its financial resources of the German plan concerned measures that support the digital transition. The plan includes measures to support the digital transformation of public services, especially public health services, and businesses. The plan also includes measures addressing human capital and investments in advanced digital technologies, with a component on the digitalisation of education.

\section{FINAL REMARKS}

The paper has highlighted the constitutional dynamics of the main decisions ensuing the Covid 19 crisis in March 2020 in different legal systems and jurisdictions, such as the European ones. The dicta examined, particularly those of the European Convention of Human Rights, as well as the ones of the Court of Justice of the European Union, but also the national ones, of

114 The debate about this matter has been particularly heated in Germany. The recent decision of the German Constitutional Court may certainly warrant such a conclusion. To elaborate, an application was lodged by 2,000 German citizens, all belonging to a political organisation led by Mr. Bernd Lucke, an economist and a politician. The subject matter of this application related to the EU decision about the public financial resources ensuing the "pandemic". More specifically, the reasons for the application were two: the first about the internal legal system; the second one concerned about the EU law. The crucial point was whether a European Union binding act/decision may be challenged because, fundamentally, it allows EU public indebtedness, without the compliance with art. 311 of the TFEU. In addition to challenging the validity of the said decision, the applicants even asked the BVG (the German Constitutional Court) to stop its implementation, via a temporary suspension of the legislative process of internal ratification of the EU decision. While the "interim injunction" was upheld, the merit of the application was later rejected by the Court. For a more in-depth analysis relating to these rulings, see in Italian A.F. ZumBinI, "Il Recovery Plan e la Corte Costitutionale Tedesca" (2021)3 DPCE-online 3265-3283.

115 It is worth noting that the Commission has positively assessed Germany's plan, based on the criteria set out in the RRF Regulation. The Commission has ascertained in detail whether the investments and reforms envisaged in Germany support the green and digital transitions; contribute to effectively addressing challenges identified in the European Semester; and strengthen its growth potential, job creation and economic and social resilience. 
a different nature, ${ }^{116}$ with their fluctuating positions, sometimes inconsistent with the ones issued before the "pandemic", are further food for thought. Ultimately, the global pandemic, as far as the EU is concerned, has shown the need for a better integration of the decision-making process in this area. ${ }^{17}$

116 A peculiar case is the one concerned with the way prisoners were treated during the Pandemic, particularly in jails where no face mask was provided to them. The French Conseil d'Etat held that this did not constitute any violation, since at the time of the compliant no case of coronavirus had occurred. See ordennance no. 444741 of $8^{\text {th }}$ October 2020.

117 The literature in this new area is already extensive. See C. De La Porte, M. D. Jensen, The next generation EU: An analysis of the dimensions of conflict behind the deal Social Policy \& Administration, 55.2: 388-402, 2021; S. Albrizio, J. F. Geli, Un análisis empírico de los factores que pueden potenciar la efectividad del programa Next Generation EU, in Boletín económico/Banco de España [Artículos], n. 4, 2021; C. CANIVENC, France Relance: point d'étape, neuf mois après son lancement, in Gestion \& Finances Publiques, (3), 115-123, 2021; M. THöNE, "Next Generation EU-der erste von vielen Schritten ist getan.", in Ifo Schnelldienst 74.2, 16-19, 2021; P. NicoletTi, Next Generation Eu e PNRR: verso quale ricostruzione? Spunti di riflessione per l'impegno delle classi dirigenti, 2021; M. Buti, G. PAPACOnSTANTInOu, The Legacy of the Pandemic: How Covid-19 is Reshaping Economic Policy in the EU, CEPR Policy Insight, 2021; J. M. HaRribey, E. JeFFERs, Plan de relance de l'Union européenne: jusqu'où peut et doit aller la BCE?. in Mouvements, (1), 116-126, 2021; M. G. FAvA, Investment Officer Italia, "Il recovery plan italiano: priorità e implementazione."; P. PAPON, Plan de relance français: des investissements d'avenir, in Futuribles, (1), 89-95, 2021; G. DomeNICI, "Next Generation EU e rinascita dell'Europa. Il Piano Nazionale italiano di Ripresa e Resilienza: verso un nuovo Rinascimento?."'in Journal of Educational, Cultural and Psychological Studies (ECPS Journal) 23 (2021); G. L. Tosato, Common debt: Next Generation is not the first case, Rome: LUISS. Policy Brief July, 2021; L. PANARo, Next Generation EU: limiti e criticità del Recovery Fund in ambito europeo e nazionale, 2021; SimONCINI, M., Le scelte chiave sul futuro dell'Europa. Il Next Generation EU alla prova della Corte costituzionale tedesca, LUISS, 2021; J. Miró, Debating fiscal solidarity in the EU: interests, values and identities in the legitimation of the Next Generation EU plan, in Journal of European Integration, 1-19, 2021; K Armingeon, C. DE la Porte, E. Heins, S. SACChi, Voices from the Past: Economic and Political Vulnerabilities in the Making of Next Generation EU, in Comparative European Politics, 2021; P. PfeIFFer, J. VARGA. Quantifying Spillovers of Next Generation EU Investment. No. 144, Directorate General Economic and Financial Affairs (DG ECFIN), European Commission, 2021; M. Passalacqua, B. Celati, Next Generation Eu: l'impresa pubblica come strumento giuridico per un intervento pubblico strategico, 413-420, 2021; F. Dorn, C. Fuest, Next Generation EU: Gibt es eine wirtschaftliche Begründung?. Ifo Schnelldienst, 74(2), 3-8, 2021; D. HowarTH, L. Quaglia, Failing Forward in Economic and Monetary Union: Explaining Weak Eurozone Financial Support Mechanisms, 2021; D. HowARTH, J. SchILD, Nein to 'Transfer Union': the German brake on the construction of a European Union fiscal capacity, Journal of European Integration 43(2): 207-224, 2021; Z. DARVAS, M. Zsolt, The nonsense of Next Generation EU net balance calculations. Bruegel, 2021; F. M. CHIODI, Next Generation EU. Una oportunidad para una Europa más fuerte, in Cultura Económica, 38(100), 95120, 2020; N. F. Fabeil, K. H. Pazim, J. LangGat, The Impact of COVID-19 Pandemic 
While during the 2007/2008 financial crisis Europe was in a position to respond with unified institutional and regulatory reforms (brand-new pan-European authorities and forward-looking regulation), paradoxically, the European post-pandemic answer has shown some uncertainty. More in detail, the financial crisis sparked off a process of integration within the financial industry, with the set-up of EU supervisors, EU regulators and, last but by no means least, more harmonised EU regulation. A top-down perspective has been implemented, giving "fresh blood" to the European Union common project. The 2020/2021 health crisis, by contrast, has not encouraged, yet, a similar debate, with discussions still straddling the internal constitutional matter, on the one hand, and the scientific discourses, on the other hand.

Crisis on Micro-Enterprises: Entrepreneurs' Perspective on Business Continuity and Recovery Strategy (May 28, 2020), in Journal of Economics and Business, Vol. 3 no. 2, 2020; F. Giovagnoli, Mauro Lombardi. "Recovery Plan e Next Generation Europe." 2020; O. PICEK, Spillover effects from next generation EU, in Intereconomics, 55(5), 325-331, 2020; M. Buti, M. Messori, Next Generation - EU: An interpretative guide, 2020; N. Levratto, "Le plan de relance pourra-t-il sauver l'industrie française?." in Revue d'économie industrielle 171.3ème, trimestre 2020 (2020): 183-200, 2020; C. Alcidi, D. Gros, Next Generation EU: A Large Common Response to the COVID-19 Crisis. Intereconomics, 55(4), 202-203, 2020; L. Codogno., P. VAn DEN NoORD, Assessing next generation EU, in LSE European Politics and Policy (EUROPP) blog, 2020; C. Bastasin, Recovery Instrument: An epochal change in political economy, SEP Policy Brief, n. 30, 2020; G. CELI, D. GuARASCIO, A. SimonAZZI, A fragile and divided European Union meetsCovid-19 further disintegration or 'Hamiltonian moment'? in Journal of Industrial and Business Economics, 47: 411-424, 2020; A. CRESPY, The EU's socioeconomic governance 10 years after the crisis: muddling through and the revolt against austerity, in Journal of Common Market Studies, 58(1):133-146, 2020; E. Jones, Next Generation EU: Solidarity, Opportunity and Confidence, European Policy analysis, European Policy analysis, Swedish Institute of European Policy Studies, accessed 15 July 2021 at https://www.sieps.se/en/publications/2021/ next-generation-eu-solidarity-opportunity-andconfidence/, 2021; S. LADI, D. TsAROUHAS, EU economic governance and Covid-19: policy learning and windows of opportunity, in Journal of European Integration 42(8):1041-1056, 2020; V. A. SснмIDT, Theorizing institutional change and governance in European responses to the Covid-19 pandemic, in Journal of European Integration 42(8): 1177-1193, 2020; J. STIGLITZ, Recovering from the Pandemic: An Appraisal of Lessons Learned, in FEPS COVID Response Papers, October 2020; F. HeInEmAnN, "Die Überdeckung der next generation EU-Schulden im Entwurf des neuen EU-Eigenmittelbeschlusses: Ausmaß und Haftungskonsequenzen." Stellungnahme anlässlich der Anhörung des Ausschusses für die Angelegenheiten der Europäischen Union des Deutschen Bundestages am 26, 2020; M. BuTI, M. Messori, Next Generation EU: Italy must not miss this opportunity, 2020; A. HinAREJos, Next Generation EU: On the Agreement of a COVID-19 Recovery Package, in European law review, (4), 451-452, 2020; F. Heinemann, "Next Generation EU: 750 Milliarden Euro suchen einen Sinn”, Ifo Schnelldienst, 74.2, 8-12, 2021; E. BAndrés, L. Gadea,V. SAlas, Y. Sauras, Spain and the European Recovery Plan, in Funcas SEFO, 9(4), 6-14, 2020. 
The new financial architecture engendered by the financial crisis shaped an integrated legislation in the three sectors of the financial industry (banks, investment firms, insurers), whereas for even more delicate and strategic matters, with constitutional implications, concerning the right of movement of individuals within the European Union, Brussels seems to be silent. Although the project of a European Union Constitution has been put on the shelves years ago, perhaps the EU loopholes and flaws of the pandemic may justify, not simply for provocative purposes, a reassessment of that project: a project that, without the - historically erratic - presence of the UK within the Union, may become not just feasible but also very successful.

As far as the pandemic is concerned, "centripetal forces" have surfaced during the darkest periods, and this has helped the closure of borders. Thus, different interpretations of the state of emergency have emerged, alongside with a "sui generis" relationship between powers and freedoms. One of the EU countries which opted mainly for the freedom, to the detriment of the unfettered power, represents a unique sample of independent decision. In the Swedish model, therefore, no compression of the freedoms was introduced, nor any limitation to the business activities. It is still debatable whether the figures concerning Sweden, after two years, may confirm that the "Swedish job" was right. In dealing with these comparisons, though, the caveat is that countries and legal systems are different from one another, so are the relevant cultures.

An open challenge is now that of the recovery after the pandemic. More specifically, a unique opportunity for Europe and its Members is to take a step forward on the bumpy path toward a European Political Union capable of strengthening a structure weakened by several earthquakes. However, this is still a difficult project that needs to be rekindled around a core concept aimed at increasing unification among European peoples (art. 1 TEU). It goes without saying that this project has never meant to be an alternative to national identities. To elaborate, there is room in Europe for a formal and substantial recognition of common rights and liberties in terms of interpretation and application as constitutional traditions common to the Member States, whose adherence is guaranteed by the European Court of Justice.

The future of the Union and that of its people depend on the way Governments will manage the recovery beyond the emergency.

The issue of solidarity, which has been evoked many times in the various difficult situations that Europe has faced since the end of the Second World War, has made an unexpected comeback in the last two years.

The debate on the possibility of identifying a political convergence in the Eurozone for the definition of a supportive European response to the on-going economic crisis, by means of common debt issuance, seems to run aground in an unceremonious manner. A formal ambiguity, which has not 
been tackled explicitly, lies behind the subtle demarcation line between the countries that call upon solidarity in favour of a common debt issuance and those that act cautiously and reluctantly. In view of the much needed debt pooling, also in order to provide suitable legal safeguards to its future repayment it is quintessential to be prepared to agree with decisional powers in the field of tax revenue as well.

The fundamental issue is the same that has hindered the achievement of common deposit insurance so far, namely the reliability of the single countries as to their capacity of meeting obligations. The political and fiscal convergence (union) is strictly connected to a full achievement of a banking union; today this deeply affects the definition of a cohesive European strategy in the field of debt issuance and fiscal transfers to overcome the on-going economic crisis.

The ultimate question is whether European citizens of each Member State are ready to share debts, as well as the respective repayment sources, and thus to delegate to Europe spheres of shared sovereignty so far bestowed upon single national and local administrations.

The pandemic crisis is not imputable to any internal economic mismanagement, but rather to an exogenous cause, which turned out to cross the geographical as well as political borders of the Member States. This has impacted on each country; as a result, a gradual process of fiscal integration needs to be considered. If Europe will manage to proceed in the direction of a European Union fiscal integration, an important model shift would result: namely, the switch from the current system, which is characterised by a common monetary policy in the Eurozone and 19 fiscal policies bound to the stability pact for the countries that belong to it, to a model featured by a common EU fiscal policy with 27 Members States, which would be accompanied by the BCE monetary policy for the Eurozone and the eight central banks of the other countries.

This new crisis, in all its tragedy, could finally be seized as a golden opportunity to overcome the twofold Eurozone-UE level, in order to move towards a more integrated Europe from a monetary, banking, fiscal and political point, based on "constitutional traditions common to the Member States of the European Union". A renovated project for those countries that wish to be part of it.

\section{BIBLIOGRAPHY}

ACCONCIAMESSA, L., COVID-19 e diritti umani: le misure di contenimento alla luce della CEDU, in Ius in Itinere, 2020.

Acocella, C., L'epidemia come metafora della sospensione e della compressione delle libertà fondamentali., in Diritti regionali, 2020. 
Alexy, R., A Theory of Constitutional Rights, with English translation by J. Rivers, Oxford, 2002 (original in German dated 1985).

Allegretti, U., Il trattamento dell'epidemia di “coronavirus” come problema costituzionale e amministrativo, in Forum Quaderni Costituzionali, 25 marzo 2020.

Arana Garcìa, E., Covid 19 y Derecho Público en España: el virus que desnudó nuestro, in Diritto pubblico dell'economia, 17th May 2020.

Azzariti, G., I limiti costituzionali della situazione d'emergenza provocata dal Covid-19, in Questione Giustizia, 27 marzo 2020; Id., Il diritto costituzionale d'eccezione, in Costituzionalismo.it, no. 1/2020, 31 marzo 2020.

BALDINI, V., Proporzionalità e adeguatezza versus prevenzione nel controllo di razionalità delle misure di contrasto all'emergenza sanitaria: tra premesse di metodo e percezioni esegetiche, in DirittiFondamentali.it, fasc. 1/2021, p. 145.

Barone, A., Il diritto del rischio, Milano Giuffrè, 2006.

Bartolini, G., Alcune questioni dell'emergenza COVID-19 in Italia in un'ottica di international disaster law, in SIDI blog - Forum Covid-19, 21 maggio 2020.

Belvisi, F., The Common Constitutional traditions and the Integration of the EU, First European Socio-Legal conference on European Ways of Law, Onati, 2005.

BotTARI, C., Alcune riflessioni sui profili organizzativi ai tempi del coronavirus, in giustizia-amministrativa.it, 4 maggio 2020.

BurAtTi, A., Quale bilanciamento tra i diritti nell'emergenza sanitaria? Due recentissime posizioni di Marta Cartabia e Giuseppe Conte, in Diritti comparati, 1 May 2020.

CARAvita, B., L'Italia ai tempi del coronavirus: rileggendo la Costituzione italiana, 18 marzo 2020, in Federalismi.it, 5.

CARRER, M., Tutela della salute e dimensione della discrezionalità a livello comparato: l' 'esperienza tedesca, in La tutela della salute tra tecnica e potere amministrativo, M. Andreis (ed), Giuffrè Editore, 2006.

CASSESE, S., La pandemia non è una guerra. I pieni poteri al governo non sono legittimi, in Il dubbio, 14.04.2020-.

Cataldi, G., Art. 15. Deroga in caso d'urgenza, in Commentario breve ala CEDU, in A. Bartole, P. De Sena e V. Zagrebelsky (eds), Padova, 2012, 555.

Cavallo Perin, R., Pandemia 2020: decreti e ordinanze d'emergenza, in Giustiziainsieme.it, 15 maggio 2020.

Cotino Hueso, L., Confinamientos, libertad de circulacion y personal, prohibicion de riuniones y actividades y otras restricciones de derechos por la pandemia del Coronavirus, in Diario La Ley, 6 April 2020, no. 9608.

Crosa, E., Il principio della sovranità dello stato nel diritto italiano, in Archivio giuridico, 1933.

Cuocolo, L., I diritti costituzionali di fronte all'emergenza Covid-19. Una prospettiva comparata, in Federalismi.it, 2020.

Cheli, E., Poteri, diritti, competenze. I problemi costituzionali sorti dal Covid, Huffingtonpost.it, 22.06.2020.

DAvEs, B., Internationale Handelsgesellschaft and the miscalculation at the inception of the ECJ's Human Rights Jurisprudence, EU Law, Cambridge, 2017.

DiceY, A.V., An introduction to the study of the law of the Constitution, 1885, London 1959, 287 ss. 
FraCCHIA, F., Coronavirus, senso del limite, deglobalizzazione e diritto amministrativo: nulla sarà più come prima?, in Il diritto dell'economia, 2020, 579 ss.

Hafner Burton, E. M., L. R. Helfer e C. J. Farris, Emergencies and Escape: Explaining Derogations from Human Rights Treaties, International Organizations, 2001, 679.

Irti, N., E. Severino, Dialogo su diritto e tecnica, Roma-Bari, Laterza, 2001.

JELlineK, G., Allgemeine Staatslehre, Berlino, 1929.

Kelsen, H., Das Problem der Souveränität und d. Theorie d. Völkerrechts, Tubinga 1920; $2^{\mathrm{a}}$ ed., 1928.

LeONARDIS, F. De, Il principio di precauzione nell'amministrazione di rischio, Milano, Giuffrè, 2005.

Lungo, D. De, Un atto di coraggio costituzionale. La Corte Suprema del Wisconsin dichiara illegittimo il Safer-at-Home Order, in Diritti comparati, 18.05.2020.

Manfredi, G., Cambiamenti climatici e principio di precauzione, in Riv. Quadr. Dir. Ambiente, 2011, p. 27.

Manzoni, A., I Promessi sposi, cap. XXXIV, 1827.

Muniz, J. N., Emergencias constitutionales y catástrofes en el ordenamiento constitucional español, in Cuadernos de Derecho Público, 172002.

Passalacqua, M., Diritto del rischio nei mercati finanziari: prevenzione, precauzione ed emergenza, Padova, Cedam, 2012.

Perfetti, L. R., Sullo statuto costituzionale dell'emergenza. Ancora sul diritto pubblico come violenza o come funzione dei diritti della persona, in P.A. Persona e Amministrazione, no. 2/2020, pp. 51-79.

Pizzorusso, A., voce Emergenza, stato di, in Enciclopedia delle scienze sociali, Treccani, 1993.

RAGGI, L., La teoria delle sovranità, Genova 1908.

Reale, G., Platone, apologia di Socrate, Bompiani, 2000.

Reнм, H., Geschichte der Staatsrechtswissenschaft, Friburgo, 1896.

RodríGuez, F. e J. Julio, Cuestiones constitucionales sobre el estado de alarma en España y la pandemia del COVID-19, in IEEE.ES 43/2020, 1.05.2020.

SAInT-Bonnet, F., Réflexions sur l'article 16 et l'état d'exception, in RDP 1998, Les quarante ans de la Constitution du 4 octobre 1958.

Spadaro, A., Do the containment measures taken by Italy in relation to COVID-19 comply with human rights law?, in EJIL Talks, 16 March 2020.

StERn, K., Das Staatsrecht der Bundesrepublik Deutschland, 3 voll., München 1977.

Sunstein, C. R., Laws of Fear: Beyond the Precautionary Principle, Cambridge, Cambridge University Press, 2005.

Sunstein, C. R., Can It Happen Here? Authoritarianism in America, New York, Dey Street, 2018.

Vermeule, A., Our Schmittian Administrative Law, in Harward Law Review, vol. 122, no. 4/2009, p. 1139. 


\title{
FROM THE PANDEMIC TO THE RECOVERY: A LEGAL ANALYSIS
}

De la pandemia a la recuperación: un análisis legal

\author{
Biancamaria Raganelli \\ Associate Professor of Economic Law (University of Tor Vergata - Rome) \\ Pierre de Gioia Carabellese \\ Fellow of Advance HE (York, UK) and Professor \\ of Business Law and Regulation (ECU, Australia) \\ http://dx.doi.org/10.18543/ed-69(2)-2021pp185-227
}

\section{Copyright}

Estudios de Deusto es una revista de acceso abierto, lo que significa que es de libre acceso en su integridad. Se permite su lectura, la búsqueda, descarga, distribución y reutilización legal en cualquier tipo de soporte sólo para fines no comerciales, sin la previa autorización del editor o el autor, siempre que la obra original sea debidamente citada y cualquier cambio en el original esté claramente indicado

Estudios de Deusto is an Open Access journal which means that it is free for full access, reading, search, download, distribution, and lawful reuse in any medium only for non-commercial purposes, without prior permission from the Publisher or the author; provided the original work is properly cited and any changes to the original are clearly indicated. 